\title{
A synthesis of early and middle Holocene coastal changes in the western Belgian lowlands
}

Vroeg en midden holocene kustevolutie van de westelijke Belgische kustvlakteeen synthese

\section{Cecile Baeteman and Pierre-Yves Declercq}

\section{(2) OpenEdition}

\section{Journals}

Electronic version

URL: http://journals.openedition.org/belgeo/15994

DOI: $10.4000 /$ belgeo.15994

ISSN: 2294-9135

Publisher:

National Committee of Geography of Belgium, Société Royale Belge de Géographie

Printed version

Date of publication: 30 June 2002

Number of pages: $77-108$

ISSN: 1377-2368

\section{Electronic reference}

Cecile Baeteman and Pierre-Yves Declercq, "A synthesis of early and middle Holocene coastal changes in the western Belgian lowlands », Belgeo [Online], 2 | 2002, Online since 01 July 2002, connection on 03 May 2019. URL : http://journals.openedition.org/belgeo/15994; DOI : 10.4000/ belgeo.15994

This text was automatically generated on 3 May 2019.

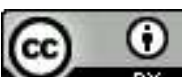

Belgeo est mis à disposition selon les termes de la licence Creative Commons Attribution 4.0 International. 


\section{A synthesis of early and middle Holocene coastal changes in the western Belgian lowlands}

Vroeg en midden holocene kustevolutie van de westelijke Belgische kustvlakteeen synthese

Cecile Baeteman and Pierre-Yves Declercq

We thank D. Smith and H. Streif for their careful refereeing of the paper and their constructive suggestions. Thanks to the numerous fieldworkers for helping in the collection of the data. This paper is a contribution to IGCP Project 437 «Coastal Environmental Change during Sea-level Highstands», and the INQUA Commission on Quaternary Shoreline and Sea-Level Changes.

\section{Introduction}

1 The aim of this paper is to present a broad scheme of coastal evolution in the western part of the Belgian coastal plain throughout the Holocene (Fig. 1). Emphasis is put on the period prior to $6000 \mathrm{cal}$ BP because this period shows major changes and illustrates the mechanism of infill of a tidal basin. Moreover, coastal evolution during this period apparently is not well understood in Belgium since in the literature it is frequently written that the coastal plain formed as from 5500 cal BP. 
Figure 1. Map of the western coastal plain of Belgium with location of the boreholes.

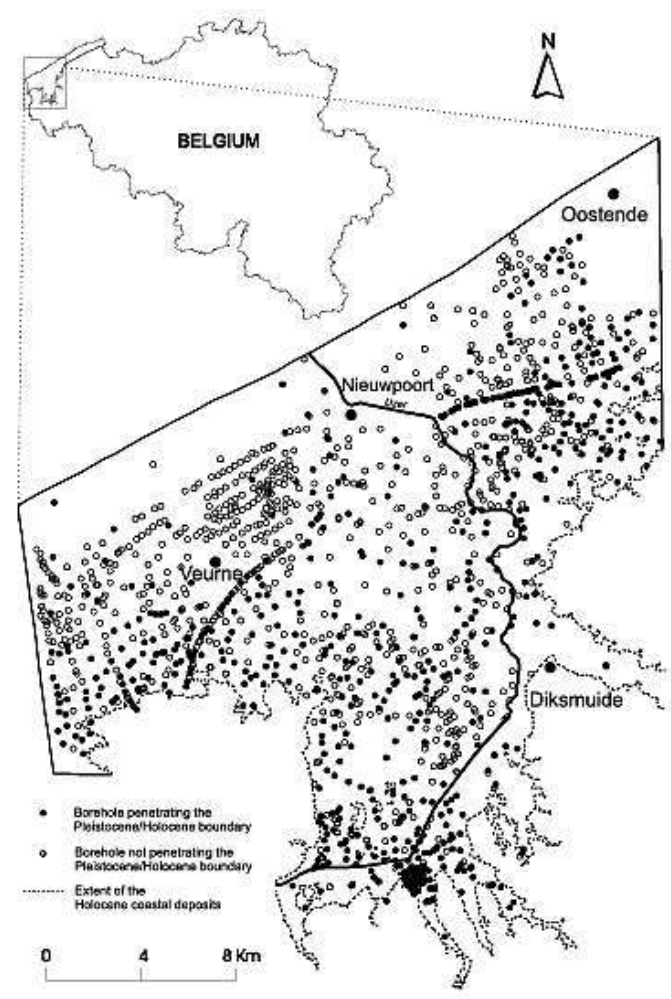

2 Since the beginning of the marine inundation of the area in the early Holocene, clastic tidal sediments and peat beds have accumulated. The Holocene sequence attains thicknesses of up to $25 \mathrm{~m}$ at the coast and thins to the south where Pleistocene deposits are outcropping (Fig. 2). The infill of the area and the associated coastal evolution will be discussed in relation to the controlling factors, i.e. the morphology of the Pleistocene surface prior to marine inundation, the rate of relative sea-level (RSL) rise, sediment supply and accommodation space (Baeteman, 1998, 1999; Beets et al., 1992; Beets and van der Spek, 2000).

Figure 2. Schematic cross-section through the sedimentary sequence of the coastal Holocene.

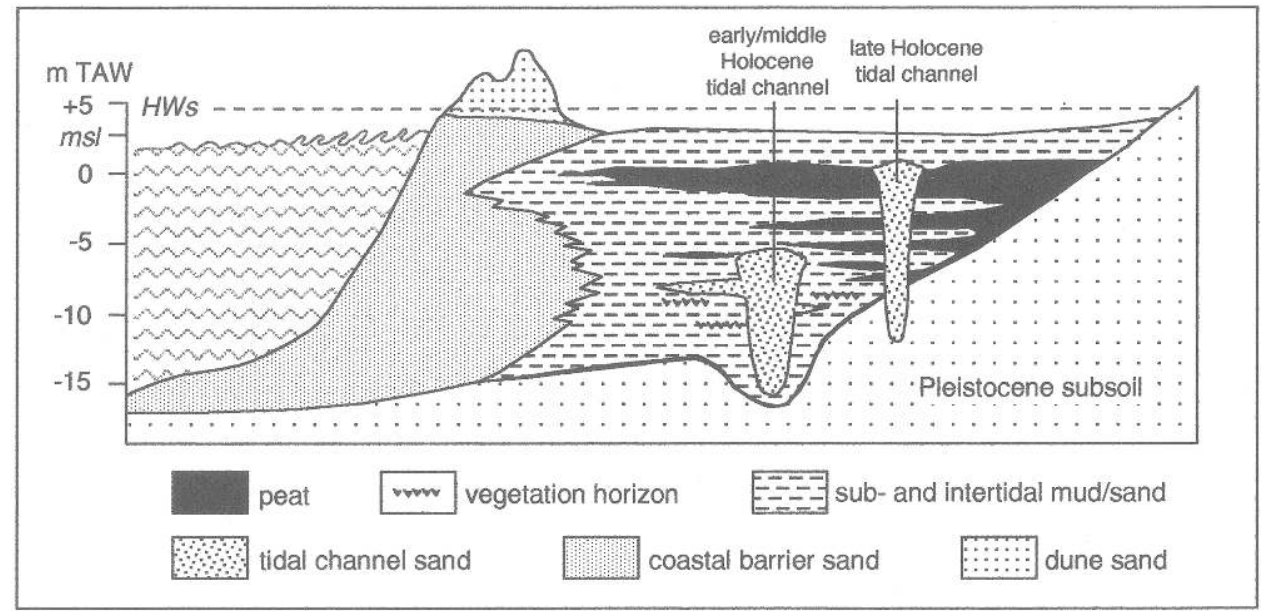


This contribution summarizes the present knowledge on coastal evolution by means of palaeogeographical reconstructions and schematical cross-sections through the Holocene accumulation wedge at various times. This paper is concerned with large-scale development of coastal evolution and not with detailed reconstructions of the sedimentary infilling requiring much more detailed maps.

\section{Study area}

4 The study area is located in the western part of the coastal plain of Belgium (Fig. 1). The latter belongs to the lowlands of the southern North Sea extending from the cliffs of northern France to Denmark in the North. The coastal plain was created through embankment and is separated from the North Sea by a closed coastal barrier and seawalls. Its elevation varies from +2 to $+5 \mathrm{~m}$ TAW, thus well below high water level (cf. Fig. 2) since the Belgian TAW datum refers to mean lowest low water spring which is about $2 \mathrm{~m}$ below mean sea level. The coast of the study area is presently characterized by a mean tidal range of $4.08 \mathrm{~m}$, and a mean spring tidal range of $4.85 \mathrm{~m}$ (Van Cauwenberghe, 1993). In the west, the plain is drained by the IJzer, a small river which is canalized and flows into the North Sea at the town of Nieuwpoort (Fig. 1). The river, together with its tributaries, drains a small and relatively low-lying basin to the south and south-west of the coastal plain.

\section{Previous work}

5 Research on the Holocene sedimentary sequence in the Belgian plain began mainly with the Soil Survey (e.g. Tavernier, 1938; Ameryckx, 1959) describing only the late Holocene sediments and putting forward hypotheses about coastal evolution. The invalidity of the hypotheses has been argued in many publications (e.g. Baeteman, 1983, 1985, 1991, 1999; Denys, 1993; Ervynck et al., 1999) and therefore will not be discussed here, although they still remain in the recent literature (e.g. Maréchal, 1992; De Moor and Pissart, 1992; Jacobs and De Ceukelaire, 2002).

Baeteman (1981) provided a first attempt at palaeogeographic reconstructions, however on the basis of a sparse borehole coverage supported by few radiocarbon dates. Thanks to the ongoing systematic mapping and survey of temporary outcrops in the western coastal plain since the early 1980s, a rather extensive geological data set of Holocene deposits and radiocarbon dates is available. Besides, several cores of the data set were analysed for diatoms in great detail in order to permit environmental interpretation and sea-level research (Denys, 1985, 1990, 1991, 1993, 1994, 1995, 1999). De Ceunynck (1985) provided palynological data for the dune area in the very western part. This new data resulted in a better understanding of sedimentary environmental interpretation and depositional history of the coastal plain, chronology of the Holocene deposits and sea-level reconstruction (Baeteman, 1985, 1991, 1993, 1999; Baeteman et al., 1999; Baeteman et al., 2002; Baeteman and Denys, 1995; Denys and Baeteman, 1995; De Ceunynck and Denys, 1987).

7 Only recently have new palaeogeographi-cal reconstructions been presented, for example the extension of the tidal inundation for various time slices between 9450 and $6000 \mathrm{cal}$ BP (Baeteman, 1999); four schematic palaeogeographic maps of respectively ca 5500-4000, ca 
3000, ca 1500 cal BP and 7th-8th century AD (Ervynck et al.,1999) and a series of detailed palaeogeographical maps of the very western part of the plain (east of Veurne, Baeteman, 2001a).

\section{Database}

8 The research methodology is based on core drilling supported by absolute age determination by radiocarbon. The data set consists of over 1150 boreholes carried out over the past 25 years in the framework of the systematic mapping of the coastal plain providing a good coverage of the area (Fig. 1). About 650 boreholes reach the Pleistocene/ Holocene boundary. As Fig. 1 demonstrates, there is a local paucity of borehole coverage along the coast because of the sand deposits of the coastal barrier. The poor distribution in the central part of the southern extension of the plain (WSW of Diksmuide) reflects the high position of the Pleistocene subsoil as inferred from the pedological map.

9 The boreholes were carried out using a hand-operated gouge auger giving undisturbed cores. About 100 boreholes were drilled mechanically covering the entire Quaternary sequence. In addition, several series of borings carried out by the Geotechnical Institute have been incorporated in the data set taking into account the lower quality of the stratigraphic data because the method of coring produced disturbed samples. The database of the Geological Survey was not used because of its low quality of sample description in that area and because most of the boreholes are too shallow.

10 All sedimentary sequences were described and analysed using the same criteria for facies identification which is based on lithology, sedimentary structures and macro fossils. Diatom analyses of several cores (Denys, 1993) confirmed the field interpretation of the different facies units. The elevation of the handborings is inferred from the topographic map. All other boreholes together with those handborings sampled for age determination, were levelled to TAW.

11140 radiocarbon dates from peat and shells were used for the palaeogeo-graphical reconstructions (Table 1). Most of the samples were analysed by the IRPA-laboratory and a few of them by the Antwerpen and Hannover Laboratories using the convential method referred to as IRPA, ANTW, Hv, respectively, and the AMS method referred to as UtC, KIA and NZA. All ages are quoted in calendar years before present (cal BP) with a two sigma age range. All dates are calibrated (Stuiver and Pearson, 1993; Stuiver and Reimer, 1993) taking into account a reservoir age of $400 \pm 40 \mathrm{BP}$ for the shells.

\section{Methodology}

A prerequisite for the reconstruction of the Holocene palaeogeography is a reliable model of the original Pleistocene relief, i.e. the morphology of the pre-transgressional surface. It is against this surface that the surface indicating RSL at any particular time is intersected, so giving the form of the tidal basin (Brew et al., 2000). The original Pleistocene relief is known when the basal peat is present (see Fig. 3), and in the areas along the landward limit of the coastal plain, where it is near to the present-day surface although basal peat never formed there just because the position of the Pleistocene subsoil is too high (see Fig. 2). Data for the original surface, however, is missing in the areas where late Holocene tidal channels eroded deeply and, in the seaward part, where in the middle Holocene, 
tidal scour removed most of the previously deposited Holocene sequence as well as the upper part of the Pleistocene deposits. Data is also missing at sites where the Holocene sequence is too thick or sandy and the Pleistocene/Holocene boundary is beyond hand auger reach. So for those areas, the original surface must be reconstructed. Figure 1 shows the borehole distribution with an indication of the known and unknown original surface (the boreholes from the Geotechnical Institute not penetrating the Pleistocene subsoil are not indicated).

Figure 3. Distribution of the basal peat.

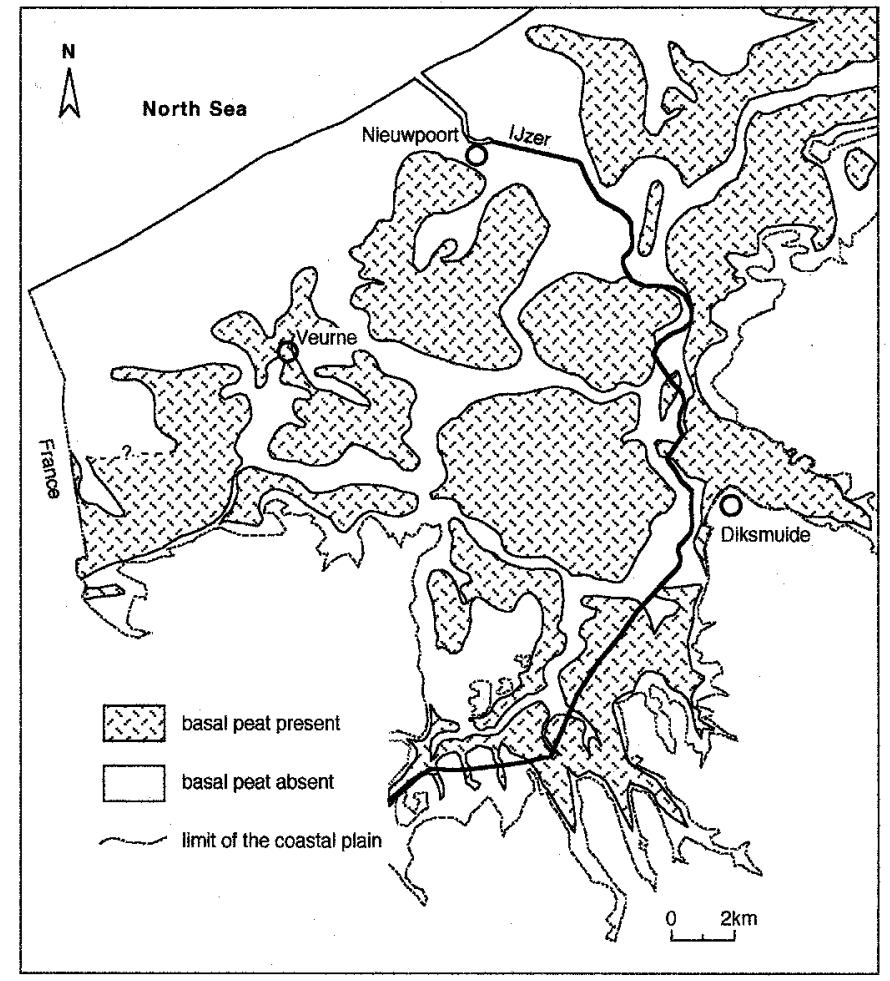

Thus the reconstruction of the original surface is based partly on exact data, partly on interpretation. Although the interpretation involves a certain measure of subjectivity (cf. Streif, 1998; Vos and Van Heeringen, 1997), certain points are taken into consideration from which data can be inferred indirectly. Boreholes with a thick Holocene sequence, but not yet reaching the Pleistocene/Holocene boundary, give information that the boundary is at least deeper than the depth of the borehole. Missing points were also inferred from borehole correlation in cross-sections. It has been observed that the late Holocene tidal channel incisions reoccupied the same location as the palaeovalleys (Baeteman, 1999) or older tidal channels (Baeteman et al., 1999). In some cases, the sedimentary record of the palaeovalley fill escaped from later erosion in restricted parts, providing valuable information about the existence of a valley in the original surface. Fig. 4 shows such an example of late Holocene channel incision (boreholes 867 and 540) in a palaeovalley fill leaving a small portion of the initial mud and peat layers (borehole 203). The remaining part of the palaeovalley was filled by sand of an early Holocene tidal channel, impossible to penetrate with the handauger. The palaeovalleys in the southern part of the plain in particular show such a favourable situation (Fig. 5). However, it is more a question of being lucky rather than the rule to find these «small portions» by 
means of boreholes and in many cases only sand-filled channels are found. In this case, the sedimentary record adjacent to the location of the late Holocene sand-filled channel must be analysed in detail. Sand deposits within a mud and peat sequence can represent sand flats, sand bars or crevasse splays which are associated with migrating tidal channels (Van der Spek and Beets, 1992; Cleveringa, 2000; Baeteman et al., 1999). So the sand deposits indicate the proximity of an early and/or middle Holocene tidal channel which most of the time occupied a palaeovalley, thus indirectly indicating the presence of a deeper Pleistocene surface.

Figure 4. Cross-section through the palaeovalley east of Nieuwpoort showing a late Holocene tidal channel incision (boreholes 867 and 540) and a portion of the mud and peat palaeovalley fill (borehole 203) indicative for the existence of a depression in the pre-Holocene surface.

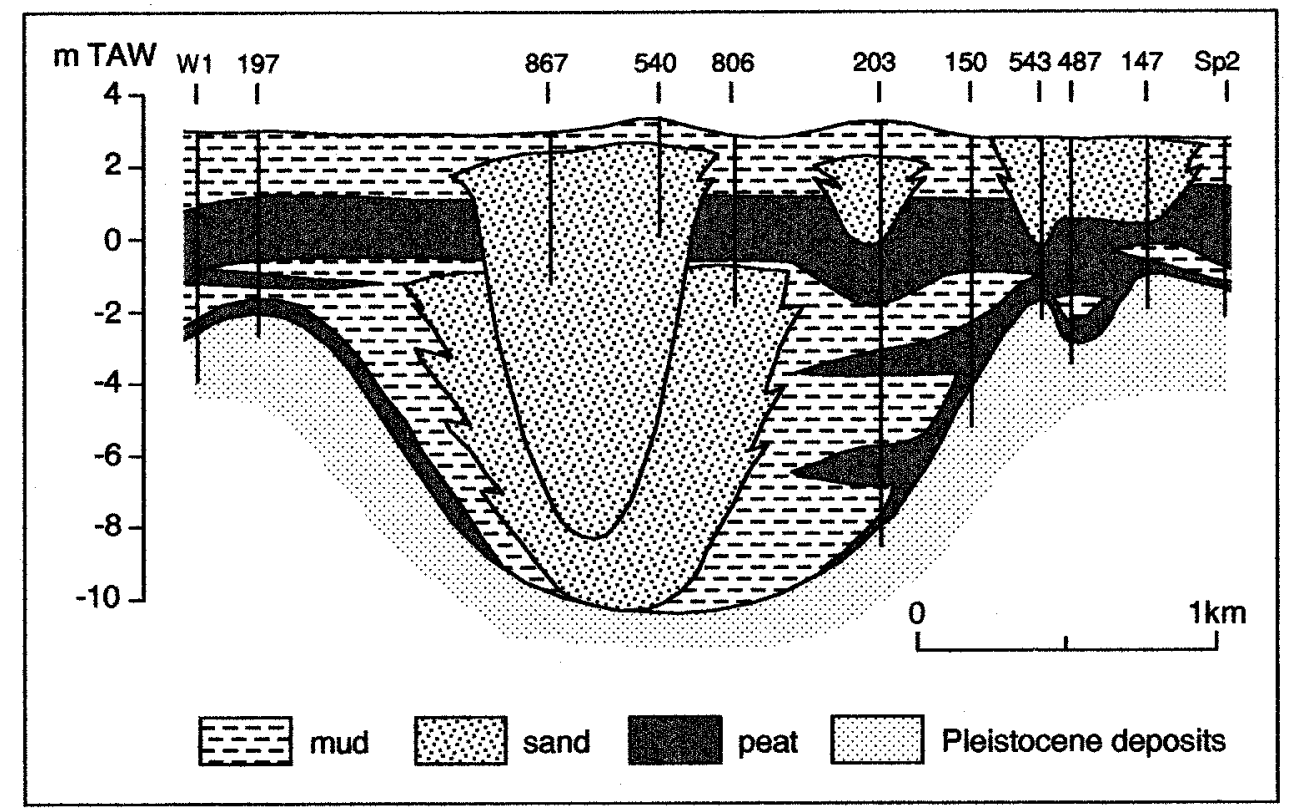


Figure 5. Simplified sequence map to illustrate a late Holocene channel incision (profile type 1 and 2) leaving a portion of the original palaeovalley fill in restricted zones (profile type 2 and 3 ).

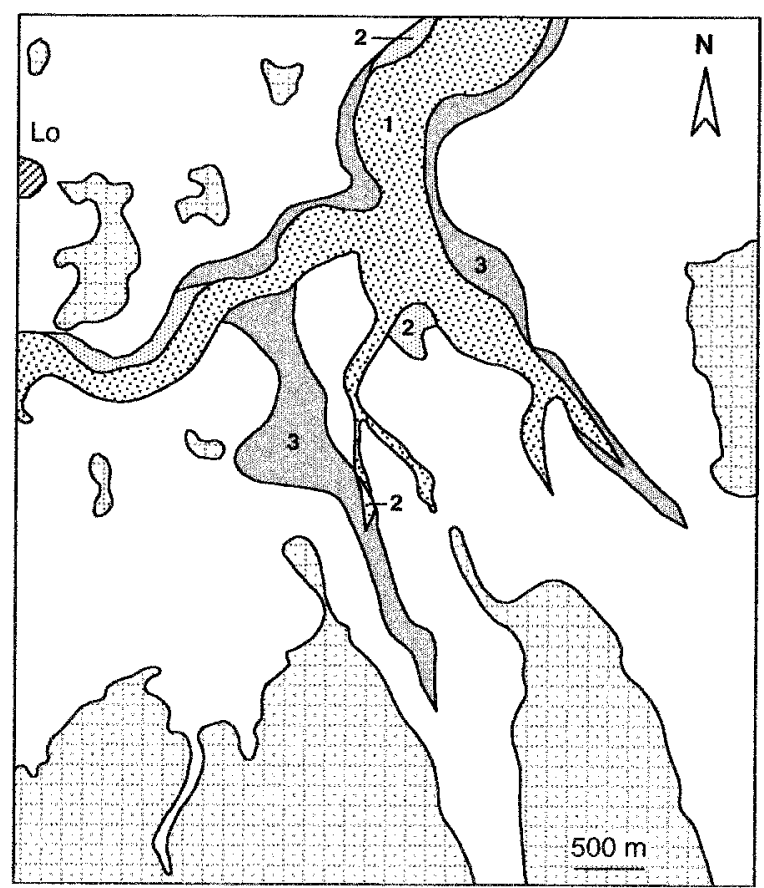

\section{Explanation of Profile Types}
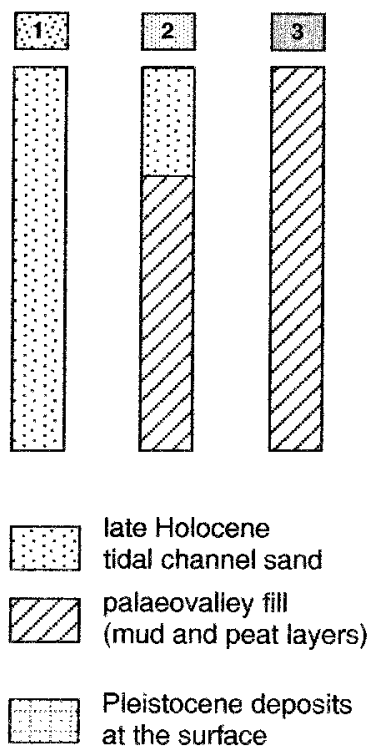

REDRAWN FROM BAETEMAN (1999)

Because of these constraints, the isohypse map (Fig. 6) of the original Pleistocene relief has been constructed manually and not by geostatistical software. It is self-evident that in areas with a low coverage of known data points, the isohypse map is more schematic than in areas with a dense data set. The morphology of the pre-Holocene surface contrasts with the contour map showing the real top of the Pleistocene deposits previously published (Baeteman, 1993, 1999). 
Figure 6. Isohypse map of the pre-Holocene surface at a $2 \mathrm{~m}$ interval relative to TAW. Due to the (inevitable) vertical exaggeration the map gives a wrong impression of the relief of the river valleys. In reality, they are shallow with gentle slopes.

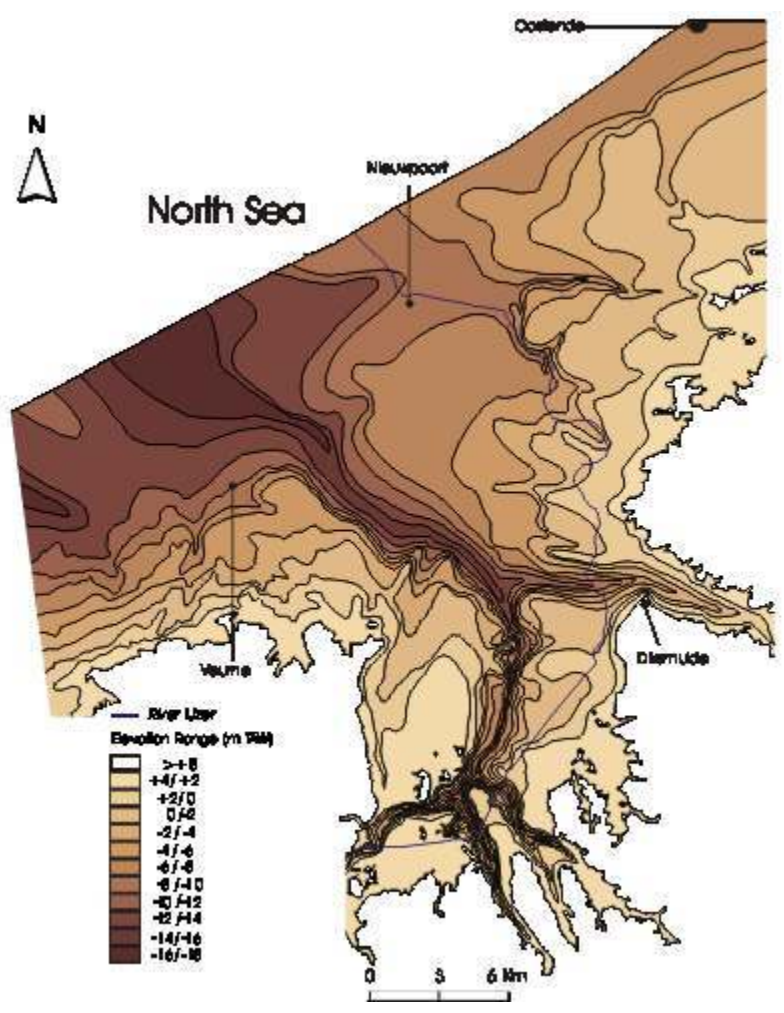

The timing of the marine inundation is recorded from dating the basal peat. In general, the basal peat is formed due to the rising groundwater level which is dependent on sea level. The post-glacial RSL rise induced the groundwater level to rise and freshwater marshes developed with peat accumulation. However, as will be demonstrated at some locations, basal peat was formed independently from the contemporary position of the sea level under the influence of local hydrological conditions. The start of the basal peat corresponds approximately to local mean high-water level (Van de Plassche, 1982; Vos and van Heeringen, 1997). The basal peat is a time-transgressive unit shifting landward and upward with the rising sea level. Thus basal peat provides a time-depth relationship. Age and elevation of the basal peat are used to construct a curve of relative sea-level rise, which in turn can be used to infer the onset of basal peat formation. So where the basal peat is missing, the contour lines of the original Pleistocene surface have been used as guidelines for time boundaries on the basis of this time-depth relationship (Vos and van Heeringen, 1997).

The contact of the basal peat with the overlying clastic unit used to construct the RSL curve, was only dated when it was not showing erosion or reworking as determined by diatom analysis (Denys, 1993; Denys and Baeteman, 1995). For the time-place estimate for the onset of marine inundation, dates of intercalated peat beds were not used because their original elevation altered due to consolidation and compaction. Only dates from sites where compaction is considered to be negligible, were used. On the other hand, the dates of the intercalated peat beds form the basis for the chronology of the sedimentary infilling of the area. 


\section{The development of the coastal plain}

17 The development of a coastal plain is a function of the following factors: rate of relative sea-level rise, morphology of the flooded surface, sediment budget and accommodation space, the latter effected by sediment and peat compaction (Baeteman, 1998; Beets and van der Spek, 2000). During the infill of the area, initially caused by the RSL rise, the relative importance of the individual factors changes in the course of time.

\section{Relative sea-level rise and sediment budget}

cal BP. This contrasts the general view in the literature where sea level starts to rise as from 5000 BP (ca. 5500 cal BP, e.g. Maréchal, 1992; Jacobs and De Ceukelaire, 2002). As will be discussed below, the depositional history of the area is mainly a function of changes in the rate of RSL rise.

19 2001a, 2001b) shows that the rate of RSL rise prior to ca. 7500 cal BP was in the order of 7 $\mathrm{m} / \mathrm{ka}$. At this high rate, the area was flooded rapidly and tidal environments shifted landward towards a position close to the present-day limit of the coastal plain. The rapid RSL rise created plenty of accommodation space so that little to no erosion occurred. Since no lagoonal environments were ever encountered, but on the contrary, vegetation horizons originating on supratidal flats, it is assumed that supply of sediment was sufficient. This is in contrast with the situation in The Netherlands where sediment supply was insufficient to compensate for the accommodation space created by the rapid RSL rise (Beets and van der Spek, 2000). In Zeeland, on the other hand, intertidal and supratidal sediments of this period were found in many places in the tidal basin implying that sedimentation rate was able to keep up with RSL rise (Vos and van Heeringen, 1997). In the study area, sediment accumulation in an intertidal and supratidal environment kept pace with the rate of RSL rise and vertical sediment accretion was dominant for the period prior to ca. $7500 \mathrm{cal}$ BP (Fig. 8). However, erosion did occur at the shoreface. At the onset of the RSL rise, most of the fluvial sediments were trapped within the estuary, reducing to nearly zero the volume of sand supplied to the adjacent shorelines (Allen and Posamentier, 1994). This resulted in coastal erosion by waves and a landward shift of the coastal barrier. The definition of a coastal barrier as described by Roy et al. (1995) will be used here, i.e. elongated, shore-parallel sand bodies, extending above sea level and consisting of a number of sandy lithofacies including beach, dune, shoreface, tidal delta, inlet and washovers. To clarify certain misconceptions, the presence of a coastal barrier does not necessarily imply the existence of well-developed aeolian deposits decorating the barrier. 
Figure 7. Relative sea-level curve for the study area.

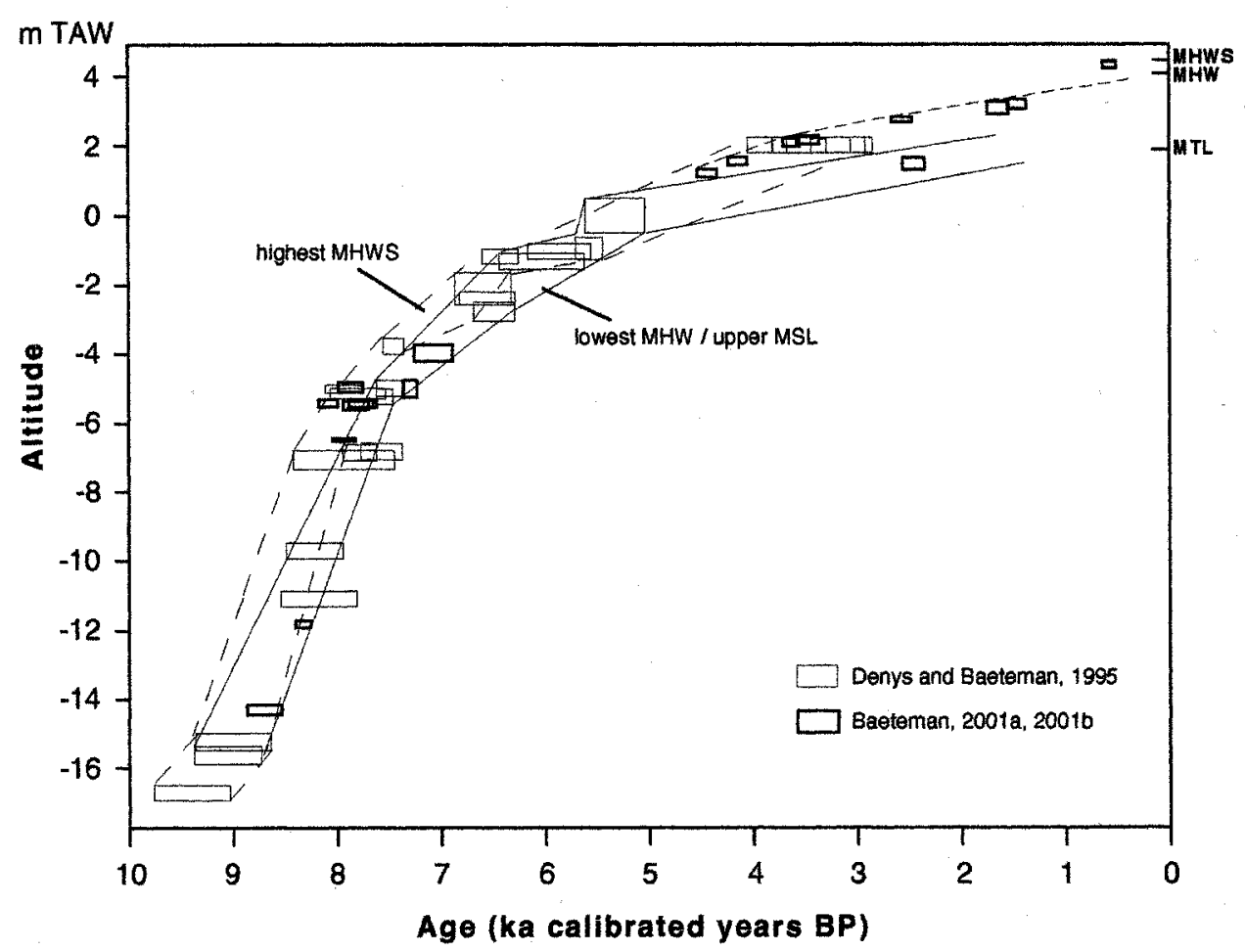

The 2 sigma standard deviations were used in constructing the error boxes. MHWS: mean high water spring tide, MSL: mean sea level, MTL: mean tide level.

FROM DENYS AND BAETEMAN, 1995, COMPLETED WITH DATA FROM BAETEMAN 2001A, 2001 B.

The rate of RSL rise dropped to ca. $2.5 \mathrm{~m} / \mathrm{ka}$ after about $7500 \mathrm{cal}$ BP. Consequently, the rapid landward shift of the tidal environments stopped and the position of the coastal barrier became more or less stable (Fig. 8). Sediment supply was now in balance with the accommodation space created by RSL rise. Periods of emergence lasted much longer and freshwater conditions prevailed for short periods (in the order of about 200 years, Baeteman et al., 1999). Salt marsh vegetation evolved into reed growth resulting in peat accumulation (Fig. 8). These freshwater marshes developed locally in the relatively higher silted-up areas which, for a certain time, were out of the reach of daily tidal flooding and consequently deprived of sediment. However, sand and mud accretion supplied by channels, continued in the nearby areas. When the latter were in turn silted up sufficiently high, meander cut-offs and crevasse splays resulted in a lateral shift of the position of the channel (Baeteman, 1998, 1999; Baeteman, et al., 1999). This happened during storm events when the water stored in the channel reached far above normal high-water level and produced ebb-flow accelerations during discharge (Cleveringa, 2000). Due to the lateral shift, the marsh area changed again into intertidal flat. The area abandoned by the channel, filled with sediment in a relatively short period (months to years, Oost and de Boer, 1994; van den Berg, 1982) and in turn evolved into salt marsh followed by freshwater marsh with peat accumulation. This process happened repeatedly and is the origin of the alternation of mud and peat beds in the sedimentary record. This sedimentary process is governed by the position of the tidal channels and thus by sediment budget and not by sea-level fluctuations such as Gullentops and Broothaers (1996) claimed in their sea-level curve whereby the sea level drops by about $1 \mathrm{~m}$ every 
time an intercalated peat bed occurs. This process, however, implies that the channel network is still migrating landwards, but at a reduced rate. The shift of the channels alternately serving and abandoning a particular part of the tidal flat continues only as long as new accommodation space is steadily being created by a sea-level rise, so that the entire channel network can continue to migrate landwards and upwards. Sediment supply must also balance the creation of accommodation space, otherwise silting up in the channel would not occur, nor would the flats silt up each time to the upper intertidal and supratidal level (Baeteman, 1999).

Figure 8. (2 figures) Schematical cross-sections from sea to land illustrating the vertical sediment accretion, the lateral expansion and the evolution of the various environments through time.

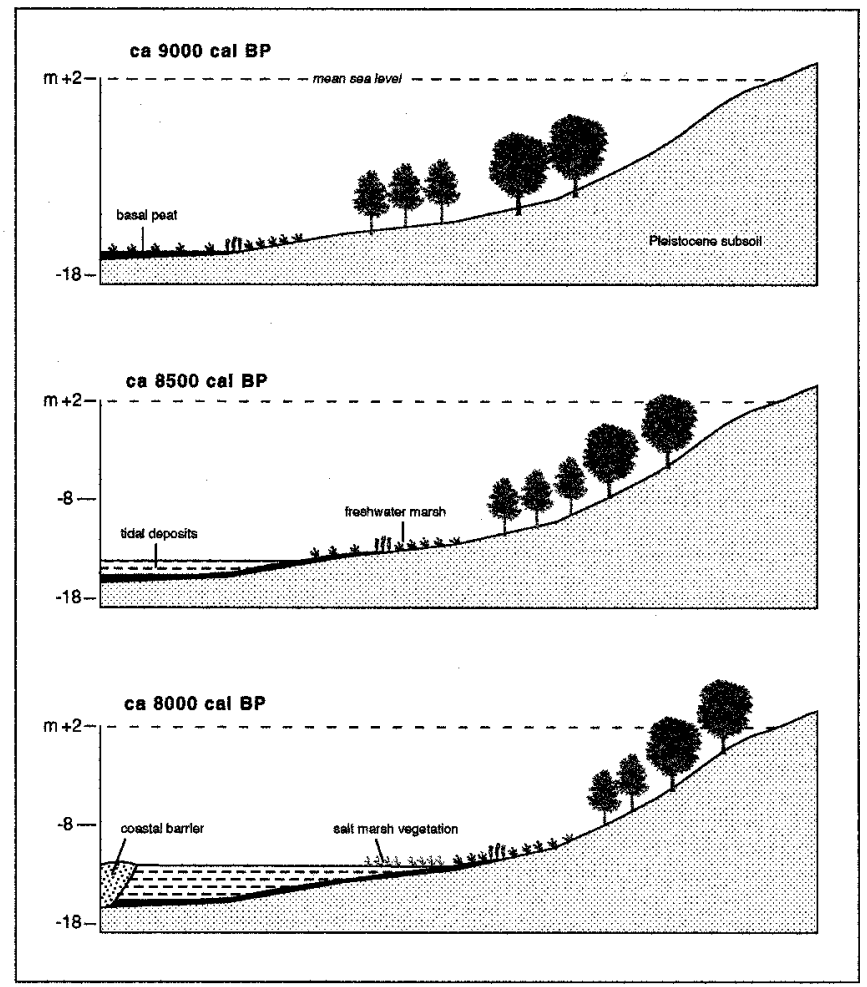




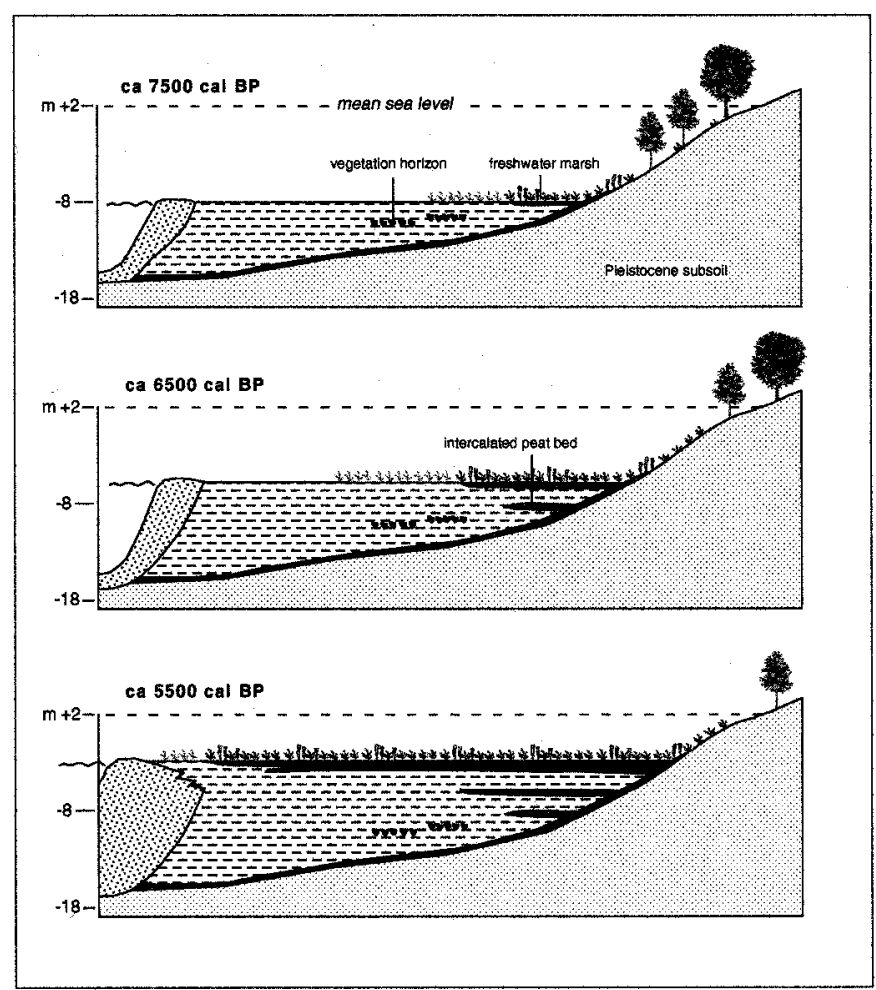

In order to simplify the evolution, a tidal channel is not incorporated. Note that the depth is relative to mean sea level and not to TAW.

In the period following the first substantial decrease in the rate of the RSL rise, the direct impact of the RSL rise is subordinate to the impact of sediment budget and the effect of local variations in the distribution of sediments.

RSL rise continued to decrease to reach an average of $0.70 \mathrm{~m} / \mathrm{ka}$ after ca. 5500-5000 cal BP. This is about the same average RSL rise as measured nowadays (Van Cauwenberge, 1993). From 5500-5000 cal BP, sea level has been close to its maximum and sediment supply has exceeded the creation of accommodation space. Landward migration of the tidal sedimentary environments has stopped completely, the stabilization of the shoreface has shifted to shoreface accretion and the shoreline has prograded beyond the present-day one (Fig. 8). Periods of peat growth have lasted longer and the lateral extension of the freshwater marshes has became more widespread. Between about 5500 and $4500 \mathrm{cal} \mathrm{BP}$, almost the entire coastal plain was changed into a freshwater marsh with peat accumulation. In the very western and seaward parts of the study area, however, tidal sedimentation went on (Baeteman, 2001a). This peat accumulation which lasted almost 3000 years, could keep pace with the slow RSL rise. No substantial coastal changes are observed for that period. Traces of tidal influence in the thick peat bed in the landward areas (Denys, 1993) suggest that the major tidal channels remained open, although they mainly served as drainage for the peat swamp. Mud intercalations in the peat bed in the seaward areas originated from local floodings in different periods ranging between about 4000 and 2500 cal BP (Baeteman and Van Strydonck, 1989). Denys (1999) however, tends to interprete these local floodings as short periods of regional significant positive tendencies in the marine influence, at least those which occurred at about 4200 cal BP and $2100 \mathrm{cal}$ BP. It is believed that the local floodings herald the end of the progradation and the re-entrance of the tidal system which led to the final fill of the plain 
(Baeteman, 1999; Baeteman et al., 1999). As mentioned above, this period will not be considered here. The mechanism and timing of the re-entrance of the tidal system is discussed in Baeteman et al. (2002) and is beyond the scope of this paper.

\section{The pre-Holocene surface}

\section{The lithology of the Pleistocene substratum}

The Pleistocene deposits in the western part of the coastal plain generally consist of clay, silt and fine sand of fluvial origin dating from the Late Pleistocene. In the seaward part, marine and coastal deposits from the Last Interglacial underlie the Holocene deposits, the fluvial portion being eroded during the middle and late Holocene (Baeteman, 1993). In the western part of the study area, the Pleistocene deposits, consisting most probably of slope deposits, are very thin and Tertiary deposits (Eocene, Kortrijk Formation, formely Ieper Clay, Jacobs and De Ceukelaire, 2002) are found in the shallow subsurface. In general, periglacial aeolian coversands from the Late Pleistocene are absent in this area.

\section{The morphology of the flooded surface}

The landscape prior to marine flooding consisted of a drainage pattern of 4 relatively small and shallow rivers joining in the central part of the plain and forming a southeastnorthwest depression (Fig. 6). This depression is interpreted as a former palaeovalley of an ancient IJzer river. Note that in the coastal plain, the present-day course of the river is located outside the palaeovalley. The small southeast-northwest running valleys in the South reach a depth of about $-8 \mathrm{~m}$. The palaeovalley has a very gentle slope with depths of $-12 \mathrm{~m}$ and $-18 \mathrm{~m}$ in the central and seaward part, respectively. The relief of the preHolocene surface contrasts greatly between the western and eastern part. The eastern part has a flat morphology, while the slope is rather steep in the west. A low and small devide in the northwest separates the palaeovalley from an elongated depression. From the data available, it is difficult to ascertain whether this depression also belongs to a valley of an ancient river system, but the presence of basal peat indicates that the depression was not formed by tidal scour processes during the Holocene flooding.

As will be shown in the palaeogeographical maps, the valleys and depression were important as conduits (in the form of tidal channels) for water and sediments of the Holocene flooding the area, and have had a significant control on the distribution of the sediments. The devide developed into a headland, but as it was low, it was eventually also flooded and the entire area was transformed into a tidal basin.

\section{Elevation model of the pre-Holocene surface}

To better visualize the relief of the palaeovalley, a 3-dimentional digital terrain model was constructed on the basis of the manually-made isohypse map. Following this, the isohypse map was geo-registered in a geographical information system (GIS) and the contour lines were digitized manually. Each polygon represents an elevation range (e.g. -2 to $-4 \mathrm{~m}$ ). A mean value was attributed to each polygon (e.g. $-3 \mathrm{~m}$ ) so that the entire surface of the polygon is fixed at the same elevation. As a result the surface appears as a staircase. This irregular surface made of polygons was then input into a TIN (Triangulated 
Irregular Network). A TIN is an object used to represent a surface (Ianko, 2002). In this case, the TIN is similar to a DEM (Digital Elevation Model). Since representation of a surface can be done in different ways (e.g. Delaunay triangulation), TIN also implies a specific storage structure of surface data. TIN divides a surface into a set of contiguous, non-overlapping triangles. A height value is recorded for each triangle node. Heights between nodes can be interpolated thus allowing for the definition of a continuous surface. TIN can accommodate irregularly distributed as well as selective data sets. With this method it is possible to represent a complex and irregular surface with a small data set, which is the case here.

A network of triangles allows the staircase aspect to be eliminated and the elevation variation can then be represented in three dimensions in a GIS (Fig. 9a). Note that the vertical exaggeration is at least 50 (10 being generally the maximum admitted) due to the weak elevation difference between the highest and lowest point (weakness of gradient). Some artifacts result from the conversion into the TIN representation, such as the connection between the two depressions in the NW part. The depressions are actually quite distinct, but the size of the most western polygon, the distance between the two depressions, and the difference in elevation are all too small to completely separate them. So the algorithm behind the TIN links the two depressions and allocates the same value to the new unit. In the smoothed version (Fig. 9b), the vertical exaggeration is changed to 100 for a better visualization.

Figure 9. Three dimentional elevation model of the pre-Holocene surface. A: TIN representation; B: smoothed representation. The present-day coastline is the seaward boundary of the model.

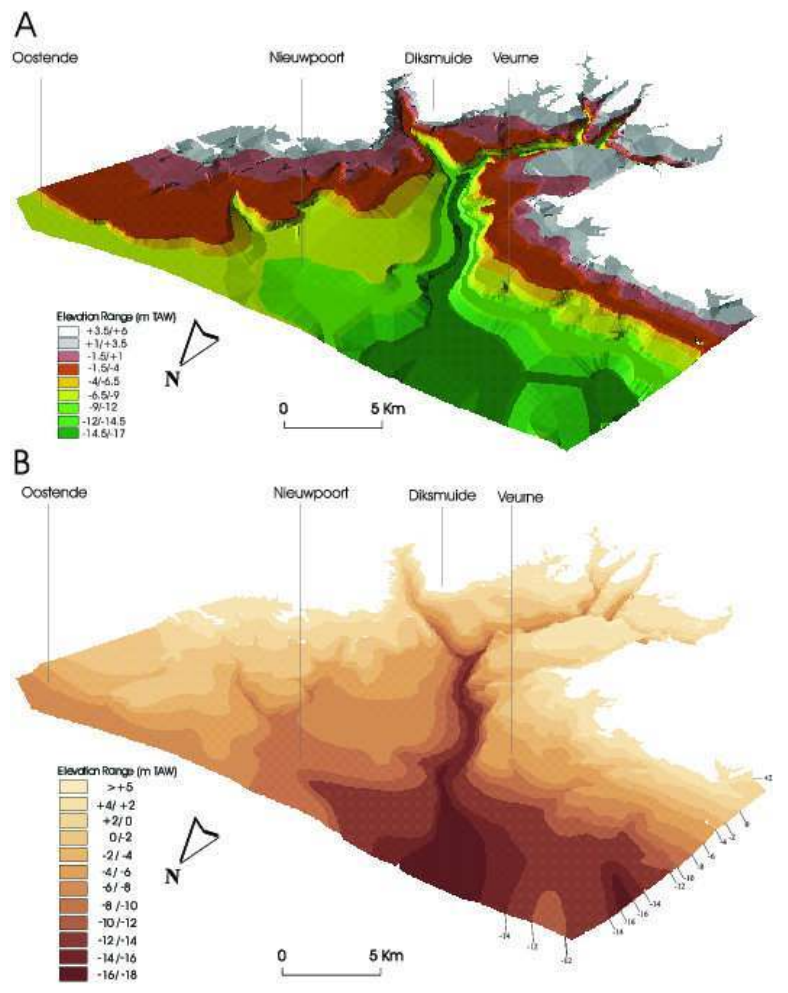




\section{Palaeogeographies of the IJzer tidal basin}

The different time slices are chosen according to the available radiocarbon dates and to
the major changes in the coastal development. Where the density of data points is low,
the reconstruction is more schematical. The borehole data and cross-sections which form
the basis for the reconstructions, are not presented in this paper. The significant ones can
be consulted in the papers mentioned above. The reconstructions for the western part are
redrawn from Baeteman (2001a). The $14 \mathrm{C}$ dates are presented in Table 1 and the numbers
in the text refer to the site numbers in the Table.

The different time slices are chosen according to the available radiocarbon dates and to
the major changes in the coastal development. Where the density of data points is low,
the reconstruction is more schematical. The borehole data and cross-sections which form
the basis for the reconstructions, are not presented in this paper. The significant ones can
be consulted in the papers mentioned above. The reconstructions for the western part are
redrawn from Baeteman (2001a). The $14 \mathrm{C}$ dates are presented in Table 1 and the numbers
in the text refer to the site numbers in the Table.

The different time slices are chosen according to the available radiocarbon dates and to
the major changes in the coastal development. Where the density of data points is low,
the reconstruction is more schematical. The borehole data and cross-sections which form
the basis for the reconstructions, are not presented in this paper. The significant ones can
be consulted in the papers mentioned above. The reconstructions for the western part are
redrawn from Baeteman (2001a). The $14 \mathrm{C}$ dates are presented in Table 1 and the numbers
in the text refer to the site numbers in the Table.

The different time slices are chosen according to the available radiocarbon dates and to
the major changes in the coastal development. Where the density of data points is low,
the reconstruction is more schematical. The borehole data and cross-sections which form
the basis for the reconstructions, are not presented in this paper. The significant ones can
be consulted in the papers mentioned above. The reconstructions for the western part are
redrawn from Baeteman (2001a). The $14 \mathrm{C}$ dates are presented in Table 1 and the numbers
in the text refer to the site numbers in the Table.

The different time slices are chosen according to the available radiocarbon dates and to
the major changes in the coastal development. Where the density of data points is low,
the reconstruction is more schematical. The borehole data and cross-sections which form
the basis for the reconstructions, are not presented in this paper. The significant ones can
be consulted in the papers mentioned above. The reconstructions for the western part are
redrawn from Baeteman (2001a). The $14 \mathrm{C}$ dates are presented in Table 1 and the numbers
in the text refer to the site numbers in the Table.

The different time slices are chosen according to the available radiocarbon dates and to
the major changes in the coastal development. Where the density of data points is low,
the reconstruction is more schematical. The borehole data and cross-sections which form
the basis for the reconstructions, are not presented in this paper. The significant ones can
be consulted in the papers mentioned above. The reconstructions for the western part are
redrawn from Baeteman (2001a). The $14 \mathrm{C}$ dates are presented in Table 1 and the numbers
in the text refer to the site numbers in the Table. tidal channel, coastal barrier and freshwater marshes or coastal peat bogs (cf. Fig. 8). The tidal flat as considered here, comprises subtidal shallow shoals, intertidal sandflats and mudflats, and supratidal salt marshes. Only the major tidal channels are represented.

We are aware that their spatial and temporal distribution is far from complete. This would require an even denser boring grid and, moreover, the pattern would still not be realistic. In the reconstruction of the earliest stages of coastal evolution, the course of the tidal channels is chosen arbitrarily because of the scarcity of sufficiently deep boreholes. The reconstruction of the position of the coastal barriers in the present-day offshore area is impossible since they dissappeared as a result of erosion. Therefore, no attempt was made to show them on the maps for the early Holocene, which does not imply that they did not exist. For the younger time slices however, few data for the coastal barrier are available (for the area around Nieuwpoort and the western part of the study area, Baeteman, 1999; Baeteman, 2001a). However, the presence and position of the coastal barrier was also inferred from associated sedimentary environments, although the major part of the position is chosen arbitrarily. The present-day shoreline is shown on the maps for reference.

This palaeogeography aims at a reconstruction of a large-scale pattern of coastal development, i.e. the progressive landward extention of the tidal basin in the course of time and the silting-up phases with peat accumulation. Therefore, short periods when tidal sedimentation prevailed, and which are recorded in the sedimentary sequence as an alternation of mud and peat, are not represented. Moreover, the presentation of the latter would require much more detailed maps. 
Table 1. Radiocarbon ages and calibration dates from the western coastal plain.

\begin{tabular}{|c|c|c|c|c|c|c|c|c|}
\hline $\mathrm{N}^{2}$ & Ste & Sample alttude $n T A W$ & Age ${ }^{10} \mathrm{C}$ yrs $3 P$ & Cal brated age y's $3^{2}$ & Ca ibrated age $2 \sigma$ range & Dated material & -a oorato ry number & Ref \\
\hline 1 & Schoudervie: & $-16.9 /$ & 99401110 & 11550 & $12100-11150$ & base basal oeat: & $12 P^{2} A 680$ & 3 \\
\hline 2 & Schouderv Ie: & -16.64 & $8440 \pm 130$ & 9440 & 9/81-9041 & top oasal peat & IRPA 681 & 3 \\
\hline 3 & Allaets & -11.27 & $8250 \pm 95$ & 9220 & $9442-8964$ & top oasal peat & IRPA 566 & 3 \\
\hline 4 & Oos:kerke & -15.60 & $81 / 0190$ & 9010 & $93 / 9-8 / 33$ & base basal neat & |RPA /34 & 3 \\
\hline 5 & Woestjn & -15.20 & $8120 \pm 100$ & 8990 & 93/0-8652 & top oasa peat & IRPA 616 & 3 \\
\hline 6 & B53 & -14.21 & $8210 \pm 40$ & 8700 & $8881-8550$ & Cerastoderma & KIA 12252 & 7 \\
\hline 7 & Sulke'tabriek & -545 & $/ 760 \perp 80$ & 8491 & $8720-8350$ & humic hor zon & $J=C 41 / 3$ & 5 \\
\hline 8 & N. Gasthuis & $-13 / / 5$ & $/ 620 \pm 90$ & $839 /$ & 8621-8136 & base basal oeat: & IRPA $6 / 8$ & 3 \\
\hline 9 & Kerkwljk & -11.70 & $7530 \pm 60$ & 8356 & $8406-8277$ & basa pea: (nean) & J:C 3802 & 12 \\
\hline 10 & 353 & -901 & $7835 \perp 40$ & 8315 & $8381-81 / 3$ & Scrobiculara & KIA 12253 & 7 \\
\hline 11 & veurne & -9.62 & $7490 \pm 130$ & 8260 & $8492-1966$ & top oasa peat & J:C 2625 & i \\
\hline 12 & Noernot & -11.02 & $7420 \pm 190$ & 8160 & $8546-7820$ & basa pea: (mean) & J:C 2626 & 11 \\
\hline 13 & Sulre tabriek & -525 & 7350145 & 8110 & $8180-8000$ & base basal neat & $J: C 3732$ & 5 \\
\hline 14 & Oth Kerk & -523 & $/ 230 \pm 85$ & 8035 & 8164-/909 & base basal oea: & IRPA S33 & 3 \\
\hline 15 & bn 363 & $-705 \leqslant 6.95$ & $7171 \pm 275$ & 7974 & $8426-7472$ & basa pea: (mean) & HV8797 & 1 \\
\hline 16 & Westende 4 & $-514 /-5.19$ & 7160185 & 7970 & $8080-7780$ & base interca ated peat & IRPA 615 & 3 \\
\hline $1 /$ & Waterhoek os & -162 & $/ 150 \pm 65$ & 7960 & $805 /-7824$ & Intercalared pea: (nea) & NLA 11948 & 12 \\
\hline 18 & Oth Kerk & -513 & $7110 \pm 90$ & 7927 & $8070-7690$ & top oasal peat & IRPA 534 & 3 \\
\hline 19 & $\operatorname{tn} A 64$ & -490 & $7080 \perp 60$ & 7900 & $7980-7755$ & tasa pea: (nean) & KIA 12243 & 12 \\
\hline 20 & 3-Grachten & -6.85 & $1030 \pm 85$ & 1854 & 8029-1669 & tasa pea: (nean) & IRPA \20 & 3 \\
\hline 21 & Sulke fabriek & -529 & $7030 \pm 55$ & 7823 & $7920-7700$ & top vasa peat & J:C 3733 & 5 \\
\hline 22 & Oos:kerke & $-748 / 744$ & $7000 \perp 80$ & 7789 & $8029-7599$ & base inte'ca ated peat & IRPA 536 & 2 \\
\hline 23 & Oos:kerke & $-3 i r / 34$ & $6 / 50 \pm 80$ & 7584 & $1 / 09-1429$ & top nterca ated oeat & $\| R>A b 36$ & 3 \\
\hline 24 & Warerhoek os & $-650\}-6.45$ & $6940 \pm 60$ & 7780 & $7867-7665$ & base gytta. & NZA 11947 & 12 \\
\hline 25 & Westende 4 & $-519 /-5.03$ & 7160185 & 7759 & $8121-7766$ & top casa peat & IRPA 614 & 3 \\
\hline 26 & Surke-abriek & $-b 19$ & $/ 340 \pm 50$ & $i / 50$ & /890-1620 & Scrobiculara & FتA 1096 & 5 \\
\hline 27 & Sulke fabriek & -529 & $6975 \pm 55$ & 7748 & $7860-7660$ & base basal oeat & RPA 1163 & 5 \\
\hline 28 & Dijk & -510 & 6870170 & 7681 & $7881-7536$ & base basal peat: & IRPA 542 & 2 \\
\hline 29 & Sulke tabriek & -520 & $6840 \pm 90$ & 7626 & $/ 830-1500$ & top oasal peat & J:C 3449 & 5 \\
\hline 30 & Oos:kerke & $-737 / 734$ & $6750 \pm 80$ & 7584 & $7709-7429$ & top nterca ated oeat & IRPA 535 & 3 \\
\hline 31 & on A78 & -597 & 6730135 & 7583 & $7664-7562$ & base basal oeat & KIA 12247 & 12 \\
\hline 32 & Waterhoek os & $-540<-535$ & $6620 \pm 60$ & 7540 & $1586-1424$ & top gytta & NLA 11946 & 12 \\
\hline 33 & Dijk & -490 & $6680 \pm 80$ & 7516 & $7631-7388$ & top oasa peat & IRPA 541 & 2 \\
\hline 34 & Sulkefabriek & -449 & 7060170 & 7507 & $7630-7370$ & liycrobia & $J=C 4175$ & 5 \\
\hline 35 & Sooorweg & $-36 i$ & $6663 \perp 60$ & 7506 & $7599-1429$ & top oøsa peat & IRPA 92/ & 3 \\
\hline 36 & Sulke fabriek & -194 & $6990 \pm 55$ & 1434 & $7550-7320$ & Cerastoderma & ₹ंA 1115 & 5 \\
\hline
\end{tabular}

\begin{tabular}{|c|c|c|c|c|c|c|c|c|}
\hline $\mathrm{N}^{\prime \prime}$ & Ste & Sample alti:ude m IAW & Age ${ }^{14} \mathrm{C}_{\mathrm{y}} \mathrm{s} \mathrm{B}^{2}$ & Caliorated age $y^{\prime} s 3^{2}$ & Calbrated age $2 \sigma$ range & Ja:ed naterial & Lavoratory fumoer & Re $e^{=}$ \\
\hline 37 & bh $A 78$ & -5.80 & $6470 \pm 50$ & 7420 & $7440-7271$ & ton basal pea: & K|A 12246 & 12 \\
\hline 38 & 3-Grachten & $-4.351-4.29$ & $6500 \pm 95$ & 7375 & $7568-7189$ & base intercalated pea: & IRPA 515 & 3 \\
\hline 39 & Sukersabriek & -3.94 & 6480195 & 7359 & $7510-7200$ & vege:ation horizon & utc 3722 & 5 \\
\hline 40 & Wovenest & $-2.77 / 2.273$ & $6420 \pm 80$ & 7296 & 7449.7179 & base intercalated pea: & IRPA 561 & 2 \\
\hline 41 & bn 755 & $-2.53 / 2.48$ & 63801115 & 7278 & $7479-7018$ & base inte'calated pea: & IRFA 724 & 12 \\
\hline 42 & Spooweg & $-2.651-2.51$ & $63 / 5 \pm 60$ & $12 / 6$ & $/ 429-11 / 9$ & base inter calated pea: & IRPA $8 / 1$ & 3 \\
\hline 43 & bา 1074 & -5.04 & 6410160 & 7276 & 7382.7219 & base oasa peat & U:C 5637 & 6 \\
\hline 44 & Suker'abriek & $-3,34$ & $6 / / 0 \pm 55$ & 1239 & $/ 380-/ 150$ & Cerastocierma & |RFA 1095 & s \\
\hline 45 & veurne & -4.62 & $6300 \pm 200$ & 7210 & $7479-6746$ & intercalated peat (mean) & utc 2637 & 6 \\
\hline 46 & Sukerabriek & $-1,94$ & $6 / 00 \pm 30$ & $/ 189$ & $/ 360-1000$ & Ostrea & UtC 4168 & s \\
\hline 47 & bา 363 & $-2.701-2.50$ & $6340 \pm 110$ & 7185 & $7289-6898$ & intercalated peat (mean) & $H \vee 8795$ & 1 \\
\hline 48 & Wo venest & $-2.67 / 2.63$ & $6200 \pm 80$ & 7164 & 7279.6857 & top nterca ared peat & IRPA 559 & 2 \\
\hline 49 & Onn Kerk & $-3.38 /-3.33$ & $6190 \pm 65$ & 7159 & $7260-6839$ & base intercalated pea: & IRPA 831 & 4 \\
\hline 50 & bา 999 & $-4.68 /-4.65$ & $6110 \pm 60$ & 7140,7008 & $7175-6884$ & base intercalated pea: & UtC 2294 & 4 \\
\hline 51 & on 1050 & -4.09 & $6240 \perp 90$ & 7100 & 7283-6891 & base oasa peat & Ute 5636 & 6 \\
\hline 52 & Sukerabriek & $-3,47$ & $6590 \pm 60$ & 7087 & $7210-6910$ & Cerastoderma & UtC 4174 & 5 \\
\hline 53 & V. Vliegreld & $-4,14$ & $6550 \perp 50$ & 7021 & $7169-6898$ & Scrobicuiaria & Ute 4862 & 12 \\
\hline 54 & bา 1004 & $-3 . / 01-3.6 i$ & $6130 \pm 100$ & 1005 & $/ 210-6 / 81$ & base inte calated pea: & UtC 262 ? & 6 \\
\hline 55 & Suker'abriek & $-3,32$ & $6110 \pm 50$ & 6967 & $7130-6850$ & top second oeat & IRPA 1074 & 5 \\
\hline 56 & Wate'hoek os & $-3.60 /-3.50$ & $6100 \pm 60$ & 694 & $/ 098-6 / 91$ & base gytta & N $\angle A 11940$ & 12 \\
\hline 57 & Westende 1 & -2.68 & $6040 \pm 80$ & 6890 & $7169-6729$ & base intercalated pea: & UtC 1537 & 8 \\
\hline 58 & bา 362 & -200 & $6015 \pm 6 \mathrm{~b}$ & 6885 & $1499-6 / 29$ & base intercalated pea: & -V $8 / 99$ & 3 \\
\hline 59 & bา 742 & -2.25 & $5970 \pm 120$ & 6846 & $7161-6494$ & base vasa peat & IRPA 725 & 3 \\
\hline 60 & Vilegveld & $-2.39 /-2.33$ & $5960 \pm 55$ & 6828 & 6984.6677 & base intercalated pea: & IRPA 849 & 8 \\
\hline 61 & & & & & & & HV $8796+$ & \\
\hline 62 & bา 363 & -2.50 & $6340 \pm 110$ & 6828 & $7289-6898$ & intercalated peat (mean) & HV 8795 & 3 \\
\hline 63 & Sukerabriek & $-2,35$ & 6330170 & 6775 & $6980-5610$ & Cerastoderma & utc 3941 & 5 \\
\hline 64 & Sukerabriek & $-3,42$ & $5900 \pm 45$ & 6733 & $6860-6640$ & base second peat & IRPA 1189 & 5 \\
\hline 65 & Spooweg & $-2.14 /-2.09$ & 5850155 & 6723 & $6845-6535$ & top nte'ca ased peat & RPA 834 & 3 \\
\hline 66 & bา $40 !$ & -2.25 & $5830 \pm 115$ & $66 / 0$ & 6892-63ذ/ & tasa peat (mean) & AVIW 136 & 12 \\
\hline 67 & Orn Kerk & $-3.011-2.95$ & 5810175 & 6668 & $6845-6449$ & top nte caared peat & IRPA 612 & 3 \\
\hline 68 & B53 & $-3.1 \%$ & $6215 \pm 35$ & $66 \vdots 4$ & $6 / / 1-6520$ & Scrobicularia & K.A 12254 & 1 \\
\hline 69 & Noordhoek & $-2.37 /-2.30$ & $5770 \pm 100$ & 6581 & $6845-6316$ & base vasal peat & RPA729 & 8 \\
\hline 10 & Noordhoek & $-2.3 / 1-2.30$ & $5 / / 0 \pm 100$ & $65 / 0$ & $6 / 90-6360$ & base intercalated pea: & $12 P A / 29$ & 3 \\
\hline 71 & Jacous & $-2.70 /-2.58$ & $5715 \pm 75$ & 6526 & $6729-6315$ & basa peat (mean) & IRPA 617 & 3 \\
\hline 72 & Waterhoek os & $-2.45 /-2.43$ & $5740 \pm 60$ & 6500 & $6666-6406$ & :op gyttja & NZA 11944 & 12 \\
\hline
\end{tabular}




\begin{tabular}{|c|c|c|c|c|c|c|c|c|}
\hline $\mathrm{N}^{2}$ & Ste & Sa nole attude $\mathrm{m} \mid \mathrm{A} W$ & Age ${ }^{14} \mathrm{C}$ yrs $3^{\circ}$ & Calorated age $y \cdot s 3^{2}$ & Cal bra:ed age $2 \sigma$ range & Dated mater|al & Laboratory numoer & $1 \mathrm{Re}^{\mathrm{s}}$ \\
\hline 73 & Spermalie 2 & -104 & $5650 \pm 70$ & 6445 & $6632-6298$ & top basa peat & RPA 519 & 1 \\
\hline 74 & Dijk & $-259 / 2.54$ & $5550 \pm 75$ & 6314 & 6523.6194 & too in:ercalated oea: & RPPA 613 & 3 \\
\hline 75 & Viegveld & -196 & 5540155 & 6312 & $6449-6279$ & oase interca ated peat & IRPA 924 & 3 \\
\hline 76 & bn 746 & -056 & $5490 \pm 100$ & 6299 & $6479-5995$ & cose basal oea: & IRPA 722 & 3 \\
\hline$\pi$ & bา 1004 & $-2 / 4 /-2.70$ & $5480 \pm 80$ & 6290 & $6456-61 / 0$ & too in:ercalated pea: & LHC 22291 & 6 \\
\hline 78 & bา 1074 & -343 & $5885 \pm 35$ & 6287 & 6399-6192 & Scrobicularia & UtC 5999 & 6 \\
\hline 19 & Waterhoek & $-231 /-2.25$ & $5400 \pm 90$ & 6195 & $6406-5951$ & too gyta & $\| R P A B / 5$ & 4 \\
\hline 80 & bา 1057 & -055 & $5395 \pm 40$ & 6195 & $6288-6167$ & base gytta & UtC 5539 & 6 \\
\hline 81 & Jacous & $-0.82 /-0.80$ & $5360 \pm 70$ & 6184 & 6299-5951 & base interca ated peat & RPA 538 & 3 \\
\hline 82 & $B 71$ & -125 & $5310 \pm 190$ & 6100 & $6479-5652$ & base basal oea: & ANTW 251 & 1 \\
\hline 83 & 3-Grachren & $-222 / 2.16$ & $5220 \pm 70$ & 5992 & $6189-5770$ & base interca ated peat & IRPA 531 & 3 \\
\hline 84 & Sulke-tabriex & $-06 i$ & $5610 \pm 55$ & 9980 & $6160-5880$ & Scrobicularia & IEFA 10/8 & s \\
\hline 85 & Violon & $-0.45 /-0.40$ & 5160170 & 5937 & $6170-5739$ & oase interca ated peat & IFPA 562 & 2 \\
\hline 86 & Sulke tabriex & -100 & $3430 \pm 55$ & 5822 & $5930-5650$ & Spistria & LtC $3 / 19$ & 5 \\
\hline 87 & oth Kerk & $-0.49 \%-0.46$ & $5130 \pm 70$ & 5923 & $6163-5729$ & base interca ated peat & IRPA 532 & 3 \\
\hline 88 & $\mathrm{~B} / 1$ & -085 & $5100 \pm 140$ & 3906 & $6189-5589$ & top basa peat & ANIW 250 & 1 \\
\hline 89 & Westende 1 & $-0.80 \%-0.75$ & $5125 \pm 55$ & 5890 & $6000-5730$ & base interca ated peat & IRPA 846 & 3 \\
\hline 90 & Suire fabriex & .700 & $5420 \pm 50$ & 5766 & $5910-5650$ & Cerastocerma & LIC 4178 & 5 \\
\hline 91 & bn 747 & +0.99 & $4990 \pm 70$ & 5732 & $5929-5589$ & base basal oea: & IRPA 723 & 12 \\
\hline 92 & Wolve nes: & - $0.53 /-0.49$ & 4970170 & 5729 & 5919-5589 & base interca ated peat & IRPA 560 & 3 \\
\hline 93 & Sooorweg & $+0.56 /+0.49$ & $4920 \pm 55$ & $s / 13$ & ๖858-54944 & oase interca ated peat & IRPA 848 & 3 \\
\hline 94 & $\operatorname{tn} 747$ & $+0.99 /+0.89$ & 4990170 & 5710 & $5900-5600$ & oase interca ated peat & IRPA 723 & 3 \\
\hline 95 & Waterhoek bs & $-1.86 j-1.84$ & $4915 \pm 60$ & 5630 & $5 / 5455 / 8$ & base interca ated peat & VZA 11943 & 12 \\
\hline 96 & B14 Bulskamp & -002 & $5280 \pm 35$ & 5622 & $5753-5543$ & Scrobicularia & KA 12255 & 7 \\
\hline 97 & Spermale 2 & $-0.39 \%-0.29$ & $4860 \pm 70$ & 5610 & $5720-5430$ & base interca ated peat & IRPA 518 & 3 \\
\hline 98 & Noernof & $+0.95 /+0.90$ & $4830 \pm 70$ & 5588 & $5729-5330$ & base s.Jface peat & IRPA 564 & 3 \\
\hline 99 & viegveld & $-1.68 /-1.64$ & 4820170 & 5570 & $5680-5390$ & tos intercalated oea: & IRPA 366 & 3 \\
\hline 100 & Suikefabrier & -277 & $5170 \pm 45$ & 5555 & $5650-5380$ & Bamea & UtC 3725 & 5 \\
\hline 101 & Sulke fabriex & -265 & 5160150 & 5545 & $5630-5340$ & Bamea & LHC 4176 & 5 \\
\hline 102 & bn 363 & +0.10 & $4800 \pm 80$ & 5509 & $5 / 28-5319$ & oase interca ated peat & HV $8 / 94$ & 3 \\
\hline 103 & Suliefabriex & -700 & $5140 \pm 50$ & 3493 & $5610-5320$ & Cerastocterna & LHC 4171 & 5 \\
\hline 104 & Oos:kerke & $+1.08 /+1.05$ & $4750 \pm 70$ & $54 / 2$ & $5649-5309$ & base interca ated peat & RPA 868 & 3 \\
\hline 105 & bn 990 & +0.14 & $4720 \pm 100$ & 5460 & $5652-5253$ & base basal oea: & UtC 2636 & 6 \\
\hline 106 & $\checkmark$ iegveld & $-1.56\}-1.52$ & $4700 \pm 70$ & 5453 & $5589-5299$ & base interca ated peat & IRPA 865 & 8 \\
\hline 107 & viegveld & $-1.56 /-1.52$ & $4700 \pm 70$ & 5400 & $5580-5280$ & base interce ated peat & RPA 865 & 3 \\
\hline 108 & Gracht 2 & +2.70 & $4660 \perp 50$ & 5400 & $5488-5287$. & case basal oea: & LHC 4143 & 12 \\
\hline
\end{tabular}

\begin{tabular}{|c|c|c|c|c|c|c|c|c|}
\hline $\mathrm{N}^{0}$ & Ste & Sa nole attude $M$ TAW & Age ${ }^{10} \mathrm{C}$ yrs $3{ }^{\circ}$ & Calibrated age y's $B^{\circ}$ & Cal bra:ed age $2 \sigma$ range & Dated material & \begin{tabular}{|l|} 
Laboratory numuer \\
\end{tabular} & $\mathrm{Re}^{t}$ \\
\hline 109 & Sulkefabriex & +0.18 & $4610 \perp 40$ & 5314 & $5450-5250$ & oase interca ated peat & IIEFA 1180 & 5 \\
\hline 110 & Dan5 & +3.25 & $4600 \pm 50$ & 5307 & $5336-5241$ & base basal oea: & UtC 4144 & 12 \\
\hline 111 & Wale 2 & +3.40 & $4560 \pm 60$ & 5293 & $5330-5029$ & base basal oea: & UAC 4145 & 12 \\
\hline 112 & Leffinge & +1.80 & $4465 \pm 220$ & 5049 & $5649-4457$ & base basal oea: & IRPA 282 & 1 \\
\hline 113 & Waterhoek & $-0.70 \%-0.66$ & $4460 \pm 60$ & 5048 & $5299-4869$ & c ayey peat & RRPA 873 & 4 \\
\hline 114 & Sulkefabriex & -246 & 4790150 & 5027 & $5240-4870$ & Cerastocterma & IFPA 1114 & 5 \\
\hline 115 & Adinkerke Autos:r & +0.93 & $4435 \pm 40$ & 5000 & 5079.4869 & base interca ated peat & IRPA 1151 & 7 \\
\hline 116 & Lekebek 2 & +3.82 & 4270170 & 4838 & $4989-4790$ & base basal sea: & UtC 4142 & 12 \\
\hline 117 & Veuwooot 2 & $+0.19 /+0.12$ & $4220 \pm 65$ & 4743 & $4964-4563$ & base interca ated peat & IRPA 726 & 3 \\
\hline 118 & GBV & +1.40 & $39 / 0 \pm 35$ & 4415 & 45244343 & oase interca ated peat & LHC 824/ & ' \\
\hline 119 & EBV & +1.60 & $3760 \pm 35$ & 4100 & $4231-4052$ & too in:ercalated oea: & LtC 8248 & 7 \\
\hline 120 & kronfort & +1.60 & $4065 \pm 35$ & 4083 & $4238-3925$ & Scrobicularie & UtC 5386 & 7 \\
\hline 121 & kronfot & +2.00 & $4060 \pm 50$ & 4077 & $4261-3894$ & Hydrobia & LtC 5527 & 7 \\
\hline 122 & Lekebek 4 & +3.25 & $3640 \pm 40$ & 3931 & $4052-3850$ & case basal oes: & IRPA 1173 & 12 \\
\hline 123 & Veuwooot 2 & $+0.61 /+0.57$ & 3580160 & 3885 & $4082-3709$ & too in:ercalated oea: & |IRPA 727 & 3 \\
\hline 124 & Wolvenes: & $+0.18 / 40.15$ & $3550 \pm 60$ & 3844 & $4065-3689$ & base interca ated peat & IRPA 860 & 3 \\
\hline 125 & Adınkerke Autos:r & +1.58 & $3550 \pm 40$ & 3835 & $3919-3 / 02$ & top oea: & IEFA 1165 & 1 \\
\hline 126 & Wupen & +1.83 & $3490 \pm 60$ & 3787 & $3961-3629$ & base interca ated peat & IRPA 527 & 3 \\
\hline $12 f$ & GBV & $+2.2 \mathrm{~s}$ & $3395 \pm 35$ & 3631 & $3 / 02-3548$ & tase peat & IEFA 123/ & f \\
\hline 128 & bn 363 & +1.75 & $3290 \pm 80$ & 3554 & $3699-3379$ & too in:ercalated oea: & HV 8793 & 3 \\
\hline 129 & $\mathrm{GBZ}$ & +2.35 & $3270 \pm 40$ & 3469 & $3579-3380$ & base reed peat & IRPA 1231 & 7 \\
\hline 130 & kronfort & +2.50 & $3055 \pm 35$ & 3260 & $3355-3201$ & vegeta:on norzon & UtC 5122 & 7 \\
\hline 131 & GBV & +3.20 & $3055 \pm 45$ & 3259 & $3360-3143$ & pea:/nunc sand & LtC 5651 & 7 \\
\hline 132 & Adinkerke Autos:r & +1.18 & $3030 \pm 40$ & $3244,3223,3217$ & 3280-310 & tase peat & IRFA 1153 & i \\
\hline 133 & GBV & +2.80 & 3020140 & 3211 & $3275-3077$ & top peat sed (erosive) & LIC 6743 & 7 \\
\hline 134 & Wupen & +2.00 & $29 / 0 \pm 60$ & $31 / 0$ & $3349-2959$ & too in:ercalated pea: & $\mid R P A D 28$ & 3 \\
\hline 135 & De Panne Stort 1 & +1.85 & $3260 \pm 60$ & 3089 & $3299-2879$ & Cerastodema & IRPA 793 & 8 \\
\hline 136 & Wolvenes: & $+0.68 /+0.63$ & $2: 10 \pm 60$ & $2 / 92$ & $2949-2749$ & too n-ercalated oea: & IRPA 859 & 3 \\
\hline 137 & Oth Kerk & $+1.10 /+1.05$ & $2690 \pm 45$ & 2782 & $2871-2749$ & too in:ercalated oea: & RPA 832 & 3 \\
\hline 138 & De Paרe $\mathrm{JO}_{2}$ & +1.95 & $2970 \pm 70$ & 2740 & $2860-2607$ & Scrobicuterie & |RPA 792 & 8 \\
\hline 139 & $\mathrm{GBZ}$ & +2.70 & $2560 \pm 40$ & 2734 & $2678-2479$ & top oea: & UtC 6730 & 7 \\
\hline 140 & viegveld & $-0.26 /-0.23$ & 2580160 & 2720 & $2800-2450$ & too in:ercalated oea: & IRPA 512 & 3 \\
\hline
\end{tabular}

Ref.: 1. Baeteman, 1981; 2. Baeteman, 1985; 3. Baeteman and Van Strydonck, 1989; 4. Baeteman 1993; 5. Baeteman et al., 1999; 6. Baeteman, 1999; 7. Baeteman, 2001a; 8. Denys, 1993; 9. De Ceunynck, 1985; 10. De Ceunynck et al., 1986; 11. Denys and Baeteman, 1995; 12. this publication. 
Figure 10. Palaeogeographical maps of the IJzer palaeovalley from 9500 to 6000 cal BP.

'soent
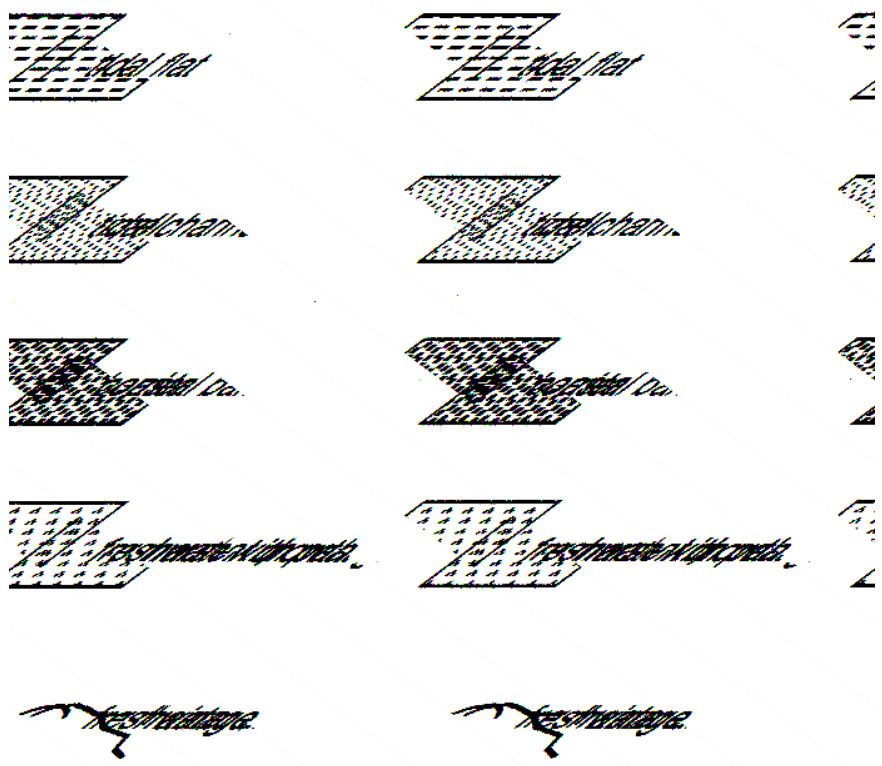

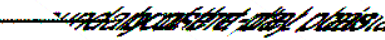

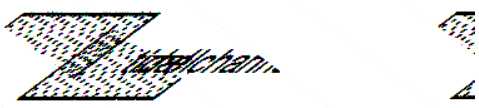

糸

L

:

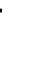


depressions. A tidal channel was installed while at the landward edge of the tidal flat, freshwater marshes with peat accumulation developed. For this period, only one borehole with a deep seated basal peat was found $\left(n^{\circ} 1\right)$. The immediately overlying clastic sediments are fine-grained and indicative of low energy environments.

Figure 10B. 9200-9000 cal BP reconstruction.

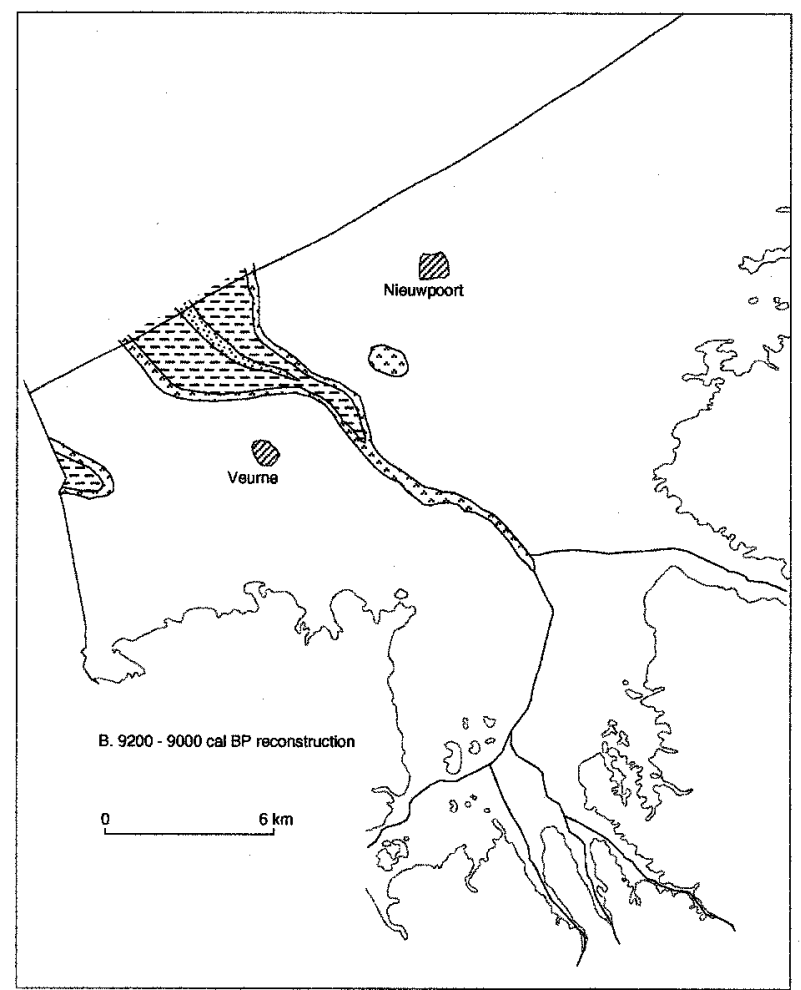

33 Although RSL rise was rapid, the lateral extension of the tidal flat was not yet substantial because of the presence of the valley. This illustrates the effect of the morphology of the flooded surface on the distribution of the sediments. However, freshwater marshes in the palaeovalley have been found as far as the central part of the plain $\left(n^{\circ} 4\right)$. One borehole $\left(n^{\circ}\right.$ 3) east of the tidal basin indicates that peat developed locally on higher ground, possibly enhanced by seepage since RSL was at about $-15 \mathrm{~m}$. 
Figure 10C. 8700 cal BP reconstruction.

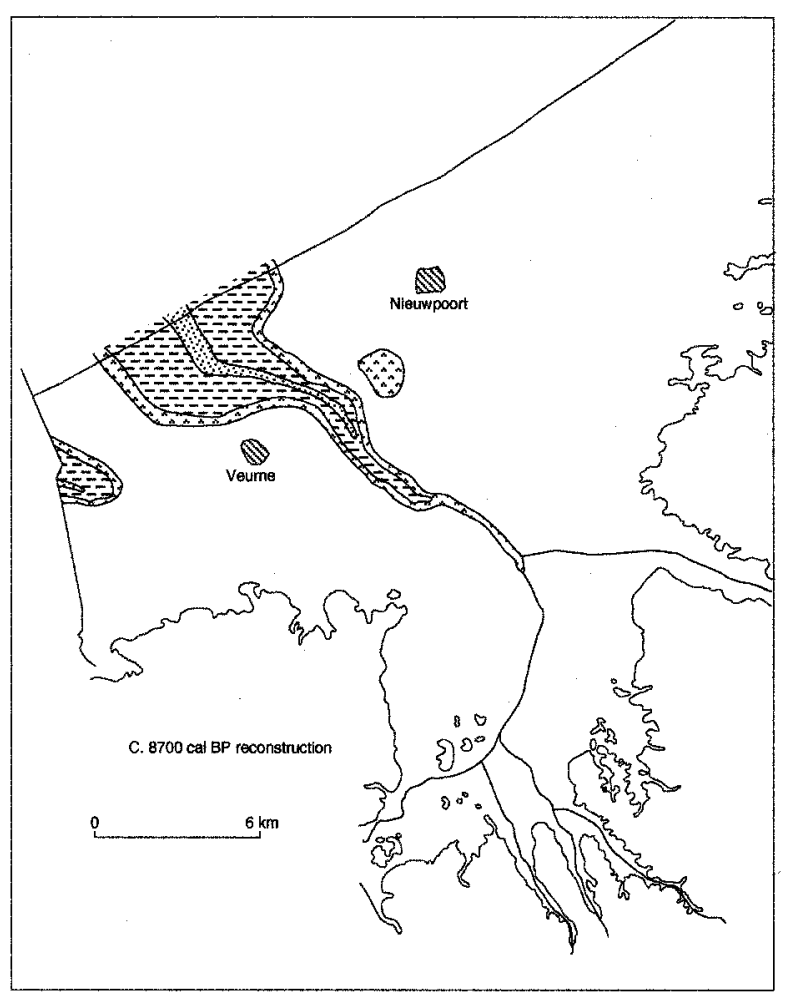

The RSL was at about $-14 \mathrm{~m}$ and the tidal flat and channel continued slowly to extend into the palaeovalley and the western depression. The presence of Scrobicularia plana $\left(\mathrm{n}^{\circ} 6\right)$ indicates that in the tidal basin a low energy environment, i.e. mudflat, prevailed. The belt of freshwater marsh, shifting upland and inland, was still narrow because the relief prevented it from lateral expansion.

Figure 10D. 8400 cal BP reconstruction. 


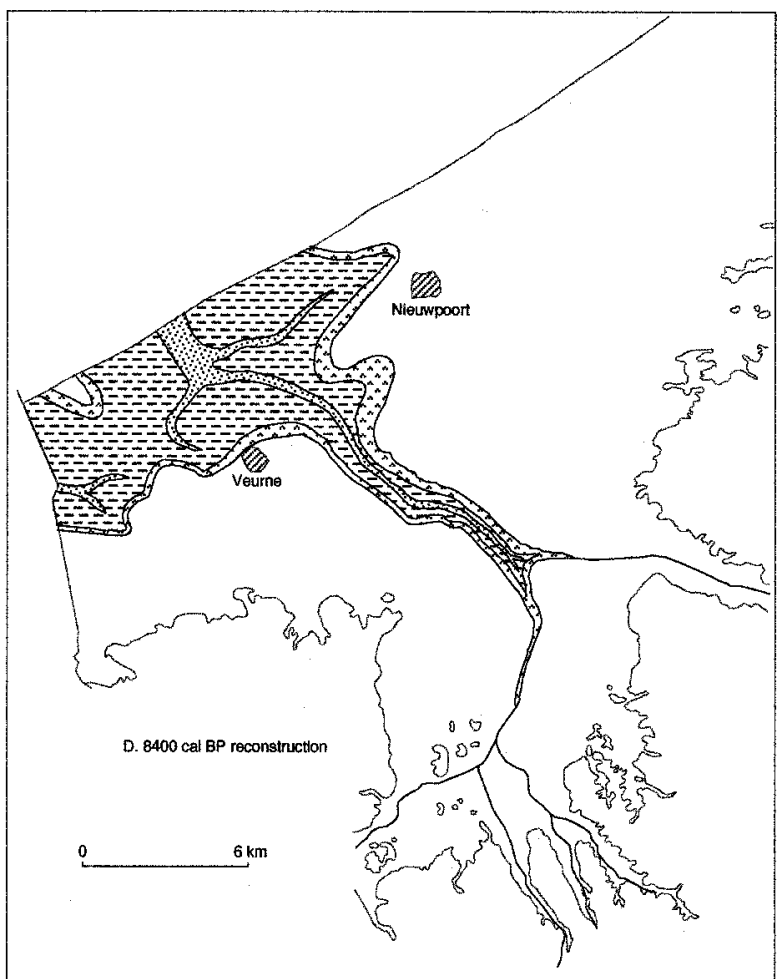

About 1000 years after the tidal system encroached the area, and after a rise of the RSL of about $6 \mathrm{~m}$, a first substantial lateral and landward expansion of the tidal flat and channels is seen, in particular in the western part. However, the headland in the NW was not yet flooded. Since no tidal flat can exist without a tidal channel, a channel has been drawn arbitrarily in the eastern extension of the tidal flat. The relatively flat relief of the Pleistocene surface resulted in a broader belt of freshwater marshes which also began to develop in two of the small rivers. 
Figure 10E. 8300-8100 cal BP reconstruction.

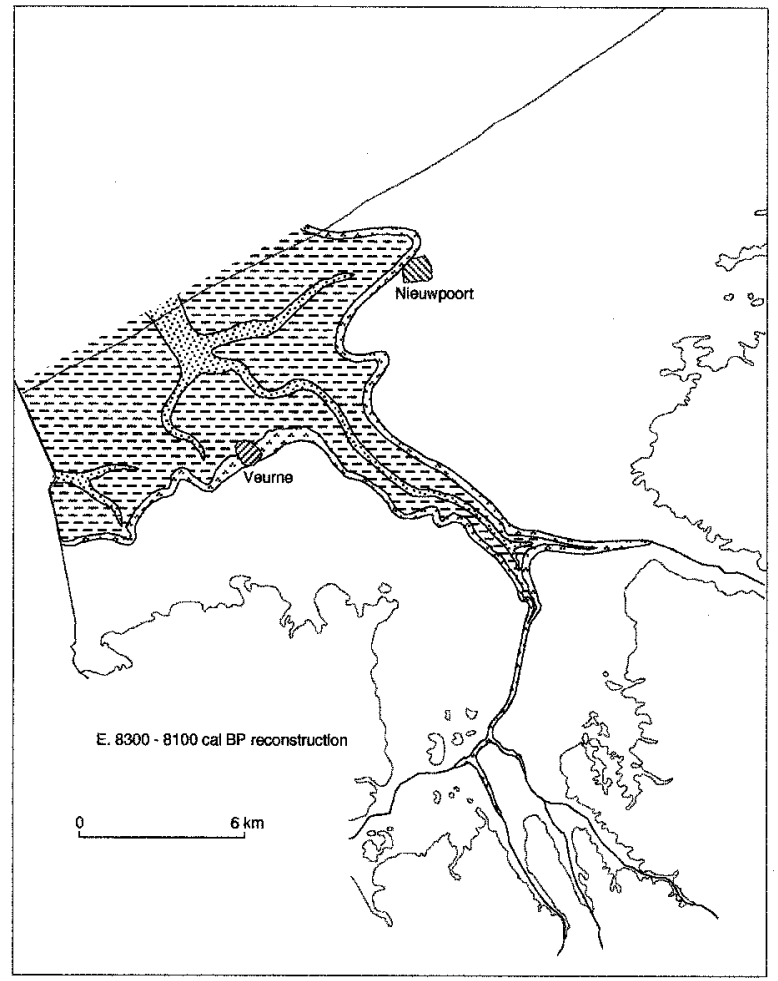

RSL was at about $-10 \mathrm{~m}$. The tidal flats extended further inland and the freshwater marshes were pushed upstream due to the RSL rise. The small river valleys, in particular, were characterized by peat growth. The coastal peat bog which developed locally east of the tidal basin has been encroached by the tidal flat, as well as the headland in the NW. 
Figure 10F. 8000-7800 cal BP reconstruction.

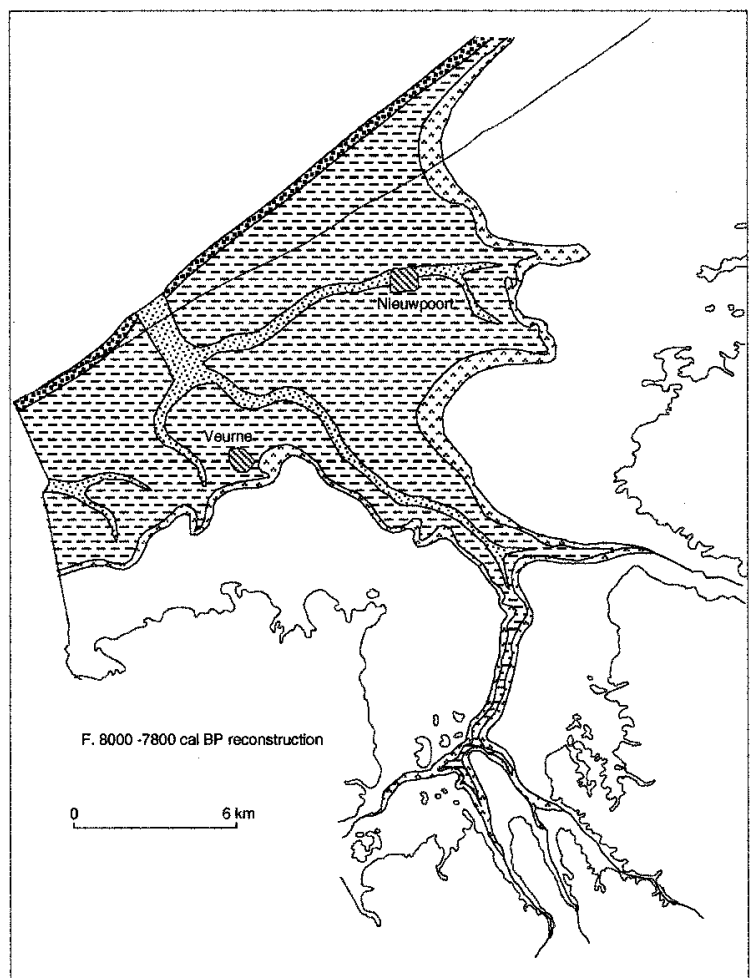

RSL was between -8 and $-7 \mathrm{~m}$. As the map shows, a substantial expansion of the tidal basin towards the west happened together with the tidal channel. Numerous cores record the development of a mudflat on the basal peat at this elevation. The tidal flat now also invaded the small river valleys far south which resulted in poor (freshwater) drainage since most of the freshwater marshes changed into permanently flooded depressions with accumulation of gyttja. In this period, the coastal barrier reached the position of the present-day coastline in the west. It is most likely that during this period the tidal scour processes began in that area. Cores show that the mudflat deposits are erosively overlain by fine sand, but on the other hand, in the area just NW of Veurne, a mudflat developed between -8 and $-3 \mathrm{~m}$ overlaying sandflat deposits, indicating low energy environments and this for a quite long period, since a Scrobicularia plana in the upper part of the mudflat deposit was dated at about $7000 \mathrm{cal}$ BP (n53). 
Figure 10G. $7750-7500$ cal BP reconstruction.

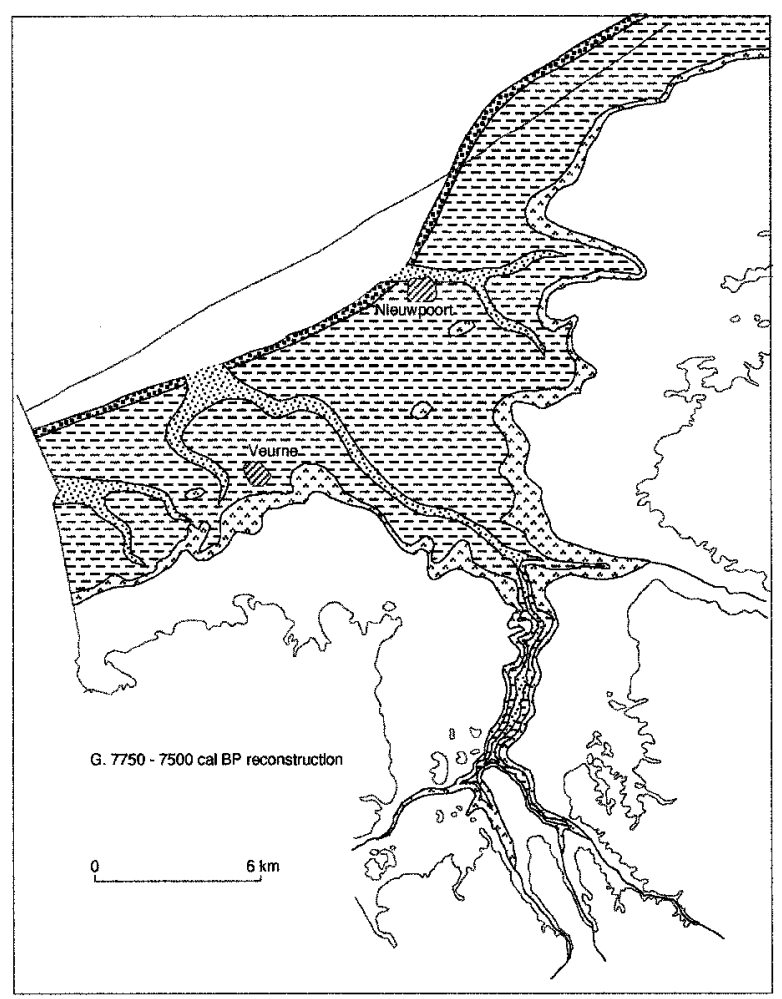

RSL was at about $-5 \mathrm{~m}$. Sedimentary records in the area of Nieuwpoort (cf. Baeteman, 1999) show that by this period, the coast had receded far inland. The eastern part of the study area was eventually flooded. This period was characterized by a decrease of the rate of RSL rise resulting in some significant changes. The landward shift of the tidal flat was much reduced, but the tidal channel now occupied the IJzer valley, even far south. This most probably resulted in an improvement of the drainage in view of the alternation of gyttja and peat in the valley fill. The channel also brought the tidal flat far south in the eastern small valley, while in the western ones, freshwater marshes developed over the tidal flat (salt marsh). Because of the reduced rate of RSL rise, peat growth at the outer edge of the tidal flat could last for a much longer time and developed over broader areas. Similar dates of basal peat are found at locations with elevation ranges between -6 and -4 $\mathrm{m}$. The tidal flat itself must have been silted up to a supratidal level for its major part because local peat growth developed. Even the tidal channel gives evidence of silting up and of a short period of peat accumulation $\left(n^{\circ} \mathrm{s} 22,23\right)$ in the area where it bifurcates into the small river valleys (not shown on the map). 
Figure $10 \mathrm{H} .7500-7000$ cal BP reconstruction.

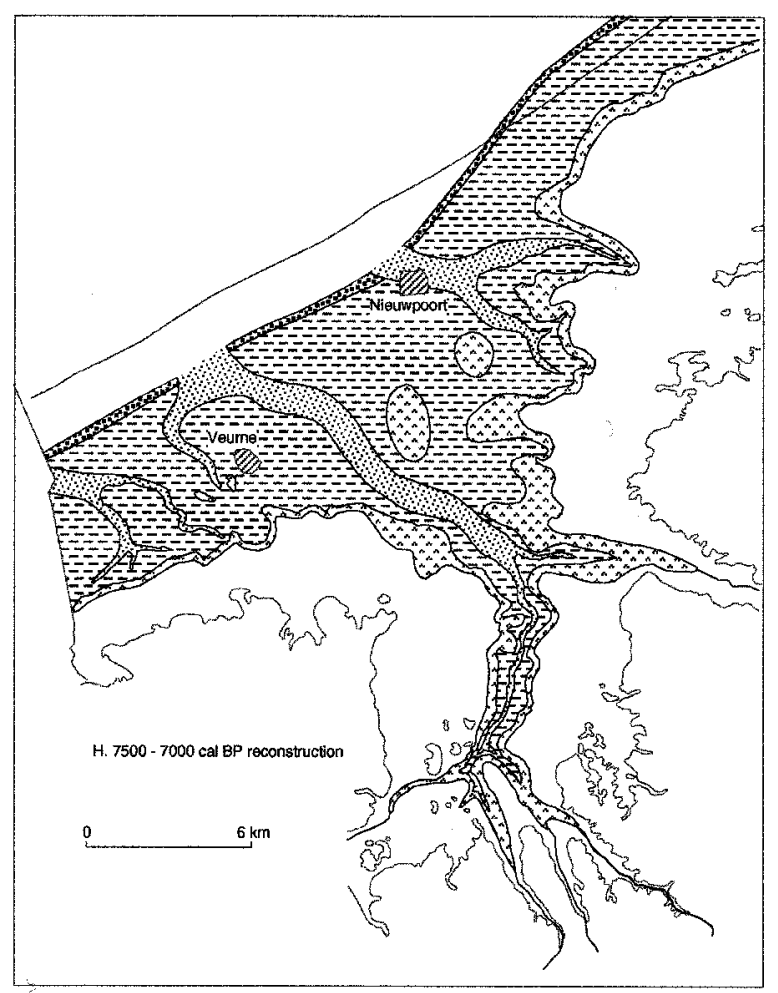

RSL reached -5 to $-4 \mathrm{~m}$. The shoreline stabilized and the extension of the tidal flat hardly changed, except in the area south of Veurne. The reduced rate of RSL rise did not create accommodation space any longer and vertical accumulation in the plain dominated. The areas with local peat growth, recorded as intercalated peat beds in the cores, became larger and more widespread. These intercalated peat beds very often merge with the peat at the landward edge of the tidal basin (the basal peat). The tidal channels expanded only a little landward. On the other hand, the channels are drawn much wider on the map. Because of lateral migration, their sand bodies were much broader, although the size of the channel itself did not change. Most probably their size was slightly reduced because of the general silting up since the cross-section of a channel is related to its tidal prism. Lateral migration became possible in this period because substantial accommodation space was not created any longer due to the reduced rate of RSL rise (van der Spek and Beets, 1992). 


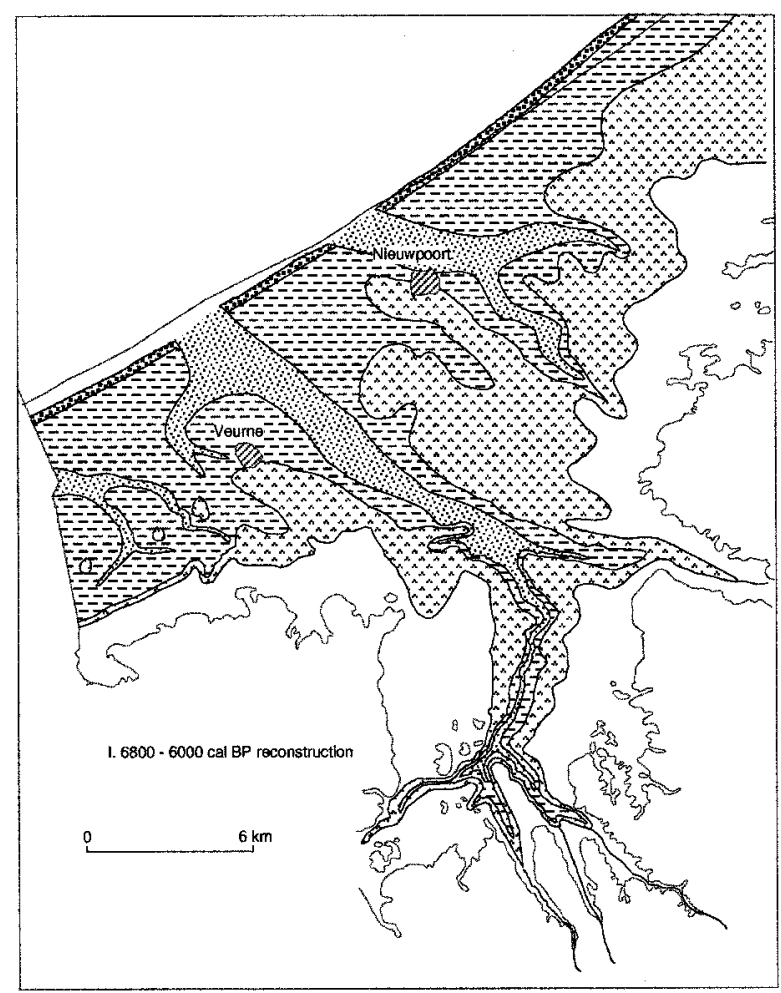

RSL was at about $-2 \mathrm{~m}$, and the shoreline had prograded, at least in the western part where the tidal basin was completely filled and sediment supply outran the creation of accommodation space through RSL rise. Freshwater marshes with peat accumulation prevailed over the major part of the area, except in the west.

41 As mentioned above, the further evolution of the coastal plain is one of very little change. The freshwater marshes became more widespread in both landward and seaward directions (cf. Fig. 8), except in the area west of Veurne. Tidal channels were also covered with peat accumulation (cf. Fig. 4). The major channels of the plain, however, remained open, most probably very much reduced in size. They acted as freshwater drainage for the peat swamp and only temporarily, tidal waters entered the channels. This situation lasted until about $2500 \mathrm{cal}$ BP when the tidal system re-entered the plain. The detailed palaeogeographical reconstruction of this re-entrance is the subject of research in progress.

\section{Final considerations}

Although this paper deals with a Holocene palaeogeographical reconstruction of the infill of the western Belgian coastal plain, its depositional history is not only of local significance. Regional comparisons with tidal basins or estuaries showing a different infill and reflecting difference in the impact of the rate of RSL rise, the relief of the preHolocene surface and the balance between the creation of accommodation space and the sediment supply, should allow to filter the relative importance (and their regional or local significance) of the various factors controlling the infill and consequently contribute to a better understanding of coastal evolution. 


\section{ABSTRACTS}

A large-scale pattern of Holocene coastal evolution of the western Belgian coastal plain has been reconstructed by means of a series of palaeogeographical maps at 9 time slices between 9.5 and 6 cal. ka BP together with schematical cross-sections of the vertical sediment accumulation. The time-depth estimate and the spatial extension of the palaeo-environments is based on the relative sea-level (RSL) curve and radiocarbon dates of (basal and intercalated) peats and shells. This paper describes the methodology of reconstructing the pre-Holocene surface and asserts that the morphology of the flooded surface is a controlling factor in the distribution of the Holocene sediments. For a better visualization of the rather weak relief, a 3D terrain model is presented. The coastal evolution is further controlled by the changes in the rate of RSL rise and sediment budget. The period before ca. 7.500 cal BP is marked by a rapid RSL rise and consequently by a progressive rapid landward migration of all depositional environments as well as a major vertical sediment accretion. In the period following the first substantial decrease in the rate of RSL rise, the direct impact of the latter is subordinate to the effect of sediment budget which is in balance with the creation of accommodation space. This resulted in the sedimentary infilling of the tidal basin and the deposition of tidal clastic sediments with peat accumulation.

Een groot-schalige reconstructie van de Holocene kustevolutie voor het westelijke deel van de Belgische kustvlakte wordt voorgesteld door middel van 9 paleogeografische kaarten voor de periode tussen 9.5 en $6 \mathrm{cal}$ ka BP, samen met schematische doorsneden van de vertikale sediment accumulatie in de tijd. De tijd en plaats bepaling van de paleomilieus is gebaseerd op de relatieve zeespiegelcurve en radiokoolstof dateringen van veen (basis- en verlandingsveen) en schelpen. Deze studie beschrijft uitvoerig de methodologie voor de reconstructie van het pre-Holoceen oppervlak. De morfologie van dit oppervlak is een bepalende factor bij de verspreiding van de Holocene sedimenten. Een 3D terrein model geeft een duidelijk beeld van het tamelijk zwakke reliëf van het oorspronkelijke Pleistocene oppervlak. De kustevolutie is mede bepaald door de snelheid van de zeespiegelstijging en het sediment budget. De aanvankelijk vlugge zeespiegelstijging in de periode voor ca. 7500 cal BP veroorzaakte een vlugge verschuiving van de sedimentaire afzettingsmilieus landinwaarts samen met een belangrijke vertikale opvulling. Een vertraging van de snelheid van de zeespiegelstijging in de daaropvolgende periode resulteerde in een verminderde invloed van de relatieve zeespiegelstijging ten opzichte van de invloed van het sediment budget dat in evenwicht was met de bergingsruimte. Daardoor kon het getijdengebied volledig opgevuld worden met clastische sedimenten afwisselend met verlandingsvenen.

\section{INDEX}

Keywords: coastal plain development, palaeogeography, pre-Holocene surface, 3D terrain model, relative sea-level rise, tidal environment, radiocarbon dates

motsclesnl kustvlakte evolutie, paleogeografie, pre-Holoceen oppervlak, 3D terrein model, relatieve zeespiegelstijging, getijde-afzettingsmilieus, radiokoolstof dateringen 


\section{AUTHORS}

\section{CECILE BAETEMAN}

Belgian Geological Survey, Jennerstraat 13, 1000 Brussels, Belgium, cecile.baeteman@naturalsciences.be

\section{PIERRE-YVES DECLERCQ}

Belgian Geological Survey, Jennerstraat 13, 1000 Brussels, Belgium 